\title{
NEK10 tyrosine phosphorylates p53 and controls its
}

\section{transcriptional activity}

Affiliations:

1: Department of Medical Biophysics, University of Toronto, Princess Margaret Cancer Research Tower, Toronto, Ontario, Canada M5G 1 L7.

2: Princess Margaret Cancer Centre, University Health Network, Princess Margaret Cancer Research Tower, Toronto, Ontario, Canada M5G $1 \mathrm{~L} 7$.

3: Center for Personalized Cancer Medicine, David H. Koch Institute for Integrative Cancer Research, Massachusetts Institute of Technology, Cambridge, MA, USA 02142.

4: Departments of Biology and Biological Engineering, Massachusetts Institute of Technology, Cambridge, MA, USA 02142.

\section{Corresponding Author:}

Vuk Stambolic

Princess Margaret Cancer Centre, University Health Network, Princess Margaret Cancer Research Tower, Room 13-313, 101 College Street, Toronto, Ontario, Canada M5G 1 L7.

\section{E-mail: vuks@uhnresearch.ca}




\section{ABSTRACT}

In response to genotoxic stress, multiple kinase signalling cascades are

30 activated, many of them directed towards the tumour suppressor p53 which coordinates

31 the DNA damage response (DDR). Defects in DDR pathways lead to an accumulation

32 of mutations that can promote tumorigenesis. Emerging evidence implicates multiple

33 members of the NimA-related kinase (NEK) family (NEK1, NEK10 and NEK11) in the

34 DDR. Here, we describe a function for NEK10 in the regulation of p53 transcriptional

35 activity through tyrosine phosphorylation. NEK10 loss increases cellular proliferation

36 through modulation of the p53-dependent transcriptional output, by directly

37 phosphorylating p53 on Y327, revealing NEK10's unexpected substrate specificity. A

38 p53 mutant at this site (Y327F) acts as a hypomorph, causing an attenuated p53-

39 mediated transcriptional response. Consistently, NEK10-deficient cells display

40 heightened sensitivity to DNA damaging agents and low NEK10 expression is an

41 independent predictor of a favorable response to radiation treatment in WT TP53 breast

42 cancer patients. 

damage response (DDR) pathways. These molecular circuits first function to recognize damaged DNA and suppress cell cycle progression, to provide time for repair of genetic material or, if the damage is deemed irreparable, carry out an apoptotic programme.

Deregulation of DDR networks leads to genetic abnormalities, chromosomal instability and accumulation of mutations that can initiate neoplastic transformation and, ultimately tumorigenesis. DDR networks are subject to complex regulation integrating multiple

54 input signals to titer the cellular response to DNA damage. One of the master regulators of the cellular response to DNA damage is the tumour suppressor TP53.

57 program, both basally and in response to various forms of cellular stress. TP53

58 transcriptional targets govern a wide range of cellular processes, including cell cycle control, apoptosis, senescence, DNA repair, metabolism, immune response and

60 migration [1-4]. p53 binds to the p53 response elements (RE) within gene promoters, 61 and transactivates a host of genes involved in cell cycle control, apoptosis and DNA

62 repair, while it represses a number of pro-growth genes $[1,5,6]$. Loss of p53 can lead 63 to genomic instability and the acquisition of oncogenic mutations that effect proliferation, transformation, therapeutic resistance and metastasis [2, 7]. TP53 germline mutations 65 are the cause of the hereditary disorders: Li-Fraumeni syndrome (LFS) and Li66 Fraumeni-like syndromes (LFL), rare diseases that lead to a predisposition to early 67 onset cancers [8]. Somatic mutations of TP53 represent some of the most frequent 
The p53 protein is modulated through multiple posttranslational modifications

70 (PTMs), including phosphorylation, ubiquitination, methylation, acetylation, and

71 SUMOylation, in response to even low levels of DNA damage or stress, that act to direct

72 and titer the cellular p53 response to elicit context-dependent phenotypic responses [3,

73 9-11]. The canonical example of this form of regulation is the MDM2-p53 axis, whereby,

74 in healthy cycling cells, p53 protein is kept at low levels by its negative regulator, the E3

75 ubiquitin ligase, MDM2 and its co-regulator MDMX [12, 13]. Following DNA damage,

ATM/ATR phosphorylates p53 on S15, disrupting its interaction with MDM2, leading to

an accumulation of p53 protein and increased transcription of multiple genes associated with the DDR [14-18]. Further, specific PTMs such as acetylation and methylation of p53 by proteins such as Tip60/hMOF, PCAF and PRTM5, also factor into the cellular decision between growth arrest and apoptosis [19-26].

Alongside p53, multiple other inputs and signalling proteins/pathways have been implicated in the control of the cellular response to DNA damage. Recently, members of the NEK kinase family have been linked to cell cycle checkpoint control and DNA repair.

84 In response to ionizing radiation (IR), NEK1 and NEK11 activity supports checkpoint integrity and DNA repair, whereas inactivation of NEK2 or NEK6 is required for proper checkpoint engagement [27-34]. Additionally, both NEK8 and NEK9 have been shown to participate in DNA repair and the response to replicative stress [35-37], whereas NEK10 has been found to control G2/M checkpoint integrity in response to ultraviolet (UV) irradiation [38].

Analyses of cancer genomes have correlated NEK10 status with cancer

91 incidence and outcome. NEK10 alterations and mutations have been reported in $2.6 \%$ 
92 of human cancers in the TCGA Pan-Cancer dataset [39-41]. Moreover, a

93 comprehensive genome wide association study (GWAS) has identified a strong breast

94 cancer susceptibility locus within a sub-region of human chromosome 3p24 containing

$95 \quad$ NEK10 [42], whereas lowered NEK10 expression has been associated with poor breast

96 cancer prognosis and higher tumour grade [38]. Despite this, little is known about the

97 function of NEK10 in tumorigenesis and in the cellular response to clinically relevant

98 forms of DNA damage.

99 In this study, we describe a function for NEK10 in the regulation of p53 100 transcriptional activity. Work in knockout cell lines lacking NEK10 demonstrates its

101 involvement in the control of cellular growth, DNA replication and sensitivity to genotoxic

102 stress. Mechanistically, we show that NEK10 regulates p53 through direct

103 phosphorylation of $\mathrm{Y} 327$ within the p53 oligomerization domain and demonstrate the 104 contribution of this phosphorylation event to the transactivation of p53-target genes.

105 Further, genomic analyses of breast cancer patient data reveals NEK10 as a candidate 106 prognostic indicator in WT TP53 tumours. 


\section{RESULTS}

\section{Loss of NEK10 leads to increased proliferation and DNA replication}

To directly investigate the biological function of NEK10, we generated A549 lung adenocarcinoma cell lines with a loss of NEK10 function by CRISPR-Cas9 mediated deletion of exon 24 of the NEK10 gene (A549 NEK10 $1 / \Delta$ cells). The targeted exon contains the "DFG" motif which is required for NEK10 protein kinase activity (Figure S1). Phenotypic characterization of $N E K 10^{\Delta / \Delta}$ cells, revealed an increase in proliferation and colony-forming ability compared to both parental A549 cells and to $N E K 10^{+/+}$single cell clones (Figure 1a-c), suggesting a growth-suppressive function for NEK10.

Despite the differences in cellular proliferation, cell cycle distributions based on propidium iodide $(\mathrm{PI})$ staining of $N E K 10^{+/+}$and $N E K 10^{\Delta / \Delta}$ cells were indistinguishable, pointing to intact basal checkpoint fidelity in the absence of NEK10 (Figure 1d). Considering that PI staining of asynchronous cells only provides a "snapshot" of the DNA content of a population of cells, we pulse-labeled cells with 5-ethynyl-2'deoxyuridine $(\mathrm{EdU})$, a nucleoside analog of thymidine that is incorporated into the DNA during active DNA synthesis. Measurement of the proportion of cells with active DNA synthesis (EdU' cells), showed increased DNA synthesis in NEK10 $0^{\Delta / \Delta}$ cells (Figure 1e). In addition, staining of cells for phosphorylated Histone $\mathrm{H} 3$ (Ser10), a mitotic marker, indicated that a higher proportion of $N E K 10^{\Delta / \Delta}$ cells were undergoing mitosis, further supporting a function for NEK10 in the control of cellular proliferation (Figure 1f). 


\section{NEK10 regulates transcription of p53 target genes}

To explore the mechanism of NEK10-mediated control of cellular proliferation and DNA synthesis, we first sought to determine the activity of the pro-growth signalling PI3K and MAPK pathways and found that there was no measureable difference in the degree of pAKT and pERK levels between the NEK10+/+ cells and NEK $10^{\Delta / \Delta}$ cells (Figure 2a) [43]. We next assessed the cellular levels of p53 and the p53-responsive genes p21 and MDM2 [44-47]. When compared to parental A549 and NEK10+/+ cells, NEK10 $1 / \Delta$ cells displayed lowered expression of p21 and MDM2 (Figure 2b). This was not due to alterations in p21 or p53 stability, as their half-lives were indistinguishable between wildtype and NEK10 knockout cell lines (Figure 2c). We next explored the mRNA levels of multiple p53 target genes (p21, p53, MDM2, GADD45a, PUMA, and BAX). Quantitative reverse transcription PCR (RT-qPCR) analysis revealed decreased mRNA expression of the p53-responsive genes p21, p53 and MDM2 in NEK10 ${ }^{\Delta / \Delta}$ cells, but not GADD45a, BAX, and PUMA (Figure 2d). Consistent with this observation, reexpression of NEK10 in NEK10 ${ }^{\Delta / \Delta}$ cells led to an increase in the expression of both p21 and MDM2, while leaving p53 levels unaffected, indicating a relationship between NEK10 and p53 transcriptional activity (Figure 2e).

\section{NEK10 phosphorylates p53 on tyrosine 327}

To determine the mechanism of $\mathrm{p} 53$ regulation by NEK10, NEK10 ${ }^{\Delta / \Delta}$ cells were stably reconstituted with WT NEK10, a kinase activity-dead mutant NEK10 D655N or a novel serine-restricted/tyrosine kinase activity-dead mutant NEK10 1693P (Figure S2 and described in the accompanying manuscript van de Kooij et al.). While overexpression of WT NEK10 led to a strong decrease in cellular proliferation (Figure 
153 3a), expression of either NEK10 D655N or NEK10 I693P led to a considerably less

154 growth suppression, supporting the notion that NEK10 kinase activity, and specifically

155 its tyrosine kinase activity, was responsible for control of proliferation. Consistent with

156 this, only the cells expressing WT NEK10 displayed elevated expression of p21 and

157 MDM2 (Figure 3b-c).

Given the observed contribution of NEK10 kinase activity to the expression of p53 target genes and growth suppression, we sought to determine if NEK10 can directly phosphorylate p53. In in vitro kinase assays, FLAG-NEK10 purified from HEK293T cells readily phosphorylated GST-p53 (Figure 4a). Further, overexpression of NEK10 in HEK293T cells led to an increase in tyrosine phosphorylated p53, indicating the potential site of phosphorylation is a tyrosine residue (Figure $4 \mathrm{~b}$ ). We next queried the Phosphosite ${ }^{\mathrm{TM}}$ database for reported sites of p53 tyrosine phosphorylation found in phospho-mass spectroscopic studies and identified 3 sites within p53 as candidate NEK10 target sites: Y126, Y220 and Y327 [48]. As both Y126 and Y220 had been

167 previously characterized as sites of Src-mediated phosphorylation [48-51], we focused on Y327 as a candidate site for NEK10 phosphorylation (Figure 4c). Interestingly, Y327

169 also fits within a recently mapped phosphorylation site motif for NEK10, with an 170 aromatic phenylalanine at the $P+1$ position (described in the accompanying manuscript 171 van de Kooij et al.). NEK10 phosphorylated a peptide encoding p53 amino acids 320172 335, but failed to phosphorylate the same peptide with a Y327F substitution (Figure 4d173 e). Despite the peptide containing two candidate phospho-acceptor sites (Y327 and 174 T329), phosphorylation of the peptide appeared to be wholly dependent on Y327 as a 175 phospho-acceptor residue, as NEK10 readily phosphorylated the T329A mutant 
176 peptide. Moreover, NEK10 failed to phosphorylate full length Y327F GST-p53,

177 reinforcing Y327 as a site for NEK10 phosphorylation (Figure 4f-g). Consistent with an

178 active function of NEK10 in p53 Y327 phosphorylation, WT p53 was tyrosine

179 phosphorylated in $N E K 10^{+/+}$but not $N E K 10^{\Delta / \Delta}$ cells, whereas the p53 Y327F mutant was not tyrosine phosphorylated in either of the cell lines (Figure 4h).

\section{NEK10 phosphorylation of p53 tyrosine 327 supports p53 transcriptional}

182

\section{activity}

We next investigated the function of Y327 in p53 transcriptional activity, by transfecting HCT116 p53-- cells with WT p53, p53 Y327F, and p53 L344P. Judging by transactivation of a panel of p53-target genes and the protein levels of both p21 and MDM2, p53 Y327F was not a full loss-of-function p53 mutant but rather acted as a hypomorph to WT p53 (Figure 5a-c). Y327F substitution impaired p53 transcriptional activity, but to a lesser extent than the one caused by the L344P mutation, which leads

to complete loss of p53 ability to influence transcription (Figure 5a-c) [52]. Even though Y327 localizes to the oligomerization domain of p53, and previously reported data indicating that nitration of this amino acid influenced oligomerization and transcriptional activity, Y327F mutation failed to impact p53 oligomerization in our system (Figure S3) $[53,54]$.

The relationship between p53 Y327 and NEK10 kinase activity was further assessed by co-expression of WT, kinase dead (A546F), or serine-restricted/tyrosine kinase activity-dead (I693P) NEK10 with WT p53 or p53 Y327F, respectively, in H1299 cells (p53-null) (Figure 5d). p21 protein levels were only increased by the co-expression of WT p53 and WT NEK10, pointing to NEK10 as an inducer of p53 transcriptional 
199

200

201

202

203

204

205

206

207

208

209

210

211

212

213

214

215

216

217 (Figure 6d). Supporting the importance of Y327 phosphorylation for the p53

activity. This effect was highly dependent on the intact $Y 327$, as the increase in p21 levels diminished in cells co-expressing WT NEK10 and p53 Y327F. Accordingly, kinase-deficient mutants of NEK10 (A546F, 1693P) failed to affect p21 levels in combination with WT p53 (Figure 5d).

Induction of p53 target genes in response to genotoxic stress requires NEK10

In light of NEK10's impact on p53 transcriptional activity and previous work implicating NEK10 in the DNA damage response [38], we next investigated the effect of NEK10 loss in the context of DNA damage. In response to cisplatin treatment, NEK10 loss impaired induction of certain p53 responsive genes, such as p21, GADD45a, and PUMA (Figure 6a). This effect was independent of p53 $\$ 15$ phosphorylation, or the fluctuations in p53 protein stability, as these remained indistinguishable between NEK $10^{+/+}$and NEK10 $10^{\Delta / \Delta}$ cells (Figure 6a). This defect in p53 activity was also observable in response to IR, as irradiation led to a rapid and sustained increase in both p21 and p53 protein levels in the $N E K 10^{+/+}$cells, reaching maximum levels 30 minutes after exposure, in contrast to the $N E K 10^{\Delta / \Delta}$ cells which took up to 4 hours to build up maximum levels of p21 expression (Figure 6b, c). Exposure of cells to IR also prompted tyrosine phosphorylation of WT p53, which was abolished by p53 Y327F substitution transcriptional response, reconstitution of $\mathrm{H} 1299$ cells (p53-null) with the p53 Y327F

219 mutant failed to fully support expression of p21 and MDM2 following IR, when compared 220 to the same cells expressing WT p53 (Figure 6e). 
We next probed the effect of NEK10 status on cellular sensitivity to escalating

222 doses of genotoxic agents using clonogenic assays. NEK10 loss led to increased cell

223 sensitivity to cisplatin and olaparib (Figure 7a-b). This effect was paralleled by the

224 impact of NEK10 loss on the DNA damage-induced cell cycle arrest. In response to

225 cisplatin treatment, and in contrast to $N E K 10^{+/+}$cells, NEK10 $10^{\Delta / \Delta}$ cells were compromised

226 in the induction of the G2/M arrest (Figure 7c-d). Compared to NEK10+/+ cells, G2/M

227 arrest defect in $N E K 10^{\Delta / \Delta}$ cells was accompanied by heightened cell death, evidenced

228 by the increased proportion of both the sub-G1 and Annexin $\mathrm{V}^{+} / \mathrm{PI}^{+}$cells, (Figure $\left.7 \mathrm{e}-\mathrm{f}\right)$.

Reduced NEK10 expression is associated with poor prognosis and

\section{increased radiosensitivity in breast cancer patients}

In light of previous evidence of genetic alterations in and around the NEK10 gene

232 in cancer [38-42, 55, 56], and the function in p53 regulation we uncovered, we sought to

233 determine if NEK10 mRNA expression related to clinical outcome in cancer. Querying

234 The Cancer Genome Atlas (TCGA), we found that reduced NEK10 mRNA expression 235 correlates with a significant decrease in 10-year survival in breast cancer patients (High

236 NEK10 vs Low NEK10) $(\mathrm{p}=0.0088)$ (Figure 8a). In agreement with our experimental

237 data, this correlation was particularly evident when TP53 status was taken into account,

238 as reduced NEK10 expression was associated with a 16\% reduction in 10-year survival

239 only in patients whose tumours were WT for TP53 $(\mathrm{p}=0.0007)$ (Figure 8b, left panel),

240 whereas no correlation was evident in patients with somatic TP53 mutations (MUT

241 TP53) (Figure 8b, right panel).

Radiotherapy is often administered as a means to prevent breast cancer

243 recurrence, and is associated with a moderate increase in overall survival $(p=0.0057)$ 
244 (Figure 8c) $[57,58]$. Interestingly, in the Low NEK10 cohort, there was a $27 \%$ increase

245 in 10-year overall survival for patients who had received radiation therapy compared to

246 those that had not $(p=0.0003)$ (Figure $8 d$, right panel). In contrast, there was no additive

247 benefit of radiation therapy in the High NEK10 patient subset (Figure 8d, left panel). The

248 radio-response of tumours with WT TP53 was highly dependent on NEK10 expression.

249 In particular, tumours from the Low NEK10 cohort were the most responsive to

250 radiotherapy, as these patients saw a $35 \%$ increase in overall survival $(p=0.0001)$

251 (Figure 8e, left panel), compared to no significant effect on survival in the High NEK10

252 cohort. In contrast, patients with somatic TP53 mutations (MUT TP53) saw a benefit

253 with radiation, but this benefit was independent of NEK10 status (Figure 8e, right panel). 


\section{DISCUSSION}

The cellular response to DNA damage is a well-orchestrated sequence of

257

258

259

260

261

262

263 274 likely indicative of an intact apoptotic axis (Figure 2d). This is reflected in equal 275 proportions of apoptotic cells under basal conditions of both $N E K 10^{+/+}$and $N E K 10^{\Delta / \Delta}$ 276 A549 cells (Figure 7e-f).

molecular events within a complex network of intersecting signaling pathways. The process is modulated in a context-dependent manner and is sensitive to the phase of the cell cycle in which the damage is encountered, the type/degree of the damage, the extracellular milieu, or the mutational status of the cell itself. Central to many of the cellular damage response pathways is the tumour suppressor p53 [2, 59, 60]. The work presented here uncovers a function for the protein kinase NEK10 in regulating p53 transcriptional activity through phosphorylation of p53 Y327.

Loss of NEK10 led to an increase in cellular proliferation and DNA replication (Figure 1). This is in contrast to the effects of deletion or knockdown of other NEK family kinases, including the close NEK10 homologues NEK6 and NEK7, whose loss of function leads to a decrease in cellular proliferation or induction of cell death [61-63]. The mechanism behind the NEK10-dependent effect on cell proliferation appeared to be related to a decrease in the expression of p53-responsive genes, key regulators of cell cycle progression (Figure 2b, d) [46, 47], as well as a decrease in p53 expression upon NEK10 loss, possibly via the auto-regulatory p53 response element that exists in the human TP53 promoter (Figure 2b, d) [64-66]. Of note, the pro-apoptotic p53 responsive genes, BAX and PUMA, were also decreased in expression but to a lesser degree, 
The differences in p53 target gene expression were dependent on the tyrosine

278 kinase activity of NEK10 (Figure 3). Using a novel serine phosphorylation-restricted

279 NEK10 mutant (I693P), we demonstrate that the NEK10 tyrosine kinase activity is

responsible for p53 regulation (Figures 3, 5d) (accompanying manuscript van de Kooij

et al.). Consistent with this, re-expression of the I693P mutant in $N E K 10^{\Delta / \Delta}$ cells failed to

augment p53 target gene expression (Figures 3b-c and 5d). Of interest, while re-

expression of kinase defective variants of NEK10 (D655N and 1693P) in NEK10 ${ }^{\Delta / \Delta}$ cells

failed to decrease cellular proliferation to the degree that WT NEK10 had, a quantifiable decrease was observed when compared to $N E K 10^{\Delta / \Delta}$ cells expressing a control vector

proliferative control (Figure 3a). Despite this, the kinase-independent function of NEK10 capable of stimulating p53 transcription (Figure 3b-c). responsive genes, p53 Y327 phosphorylation may establish a separate threshold for transactivation of subsets of p53 targets as the Y327F mutant induces an intermediate level of p53 target gene expression when compared to WT p53 and the loss of function 296 p53 L344P mutant for the majority of genes assayed, reflective of the partial loss of p53 297 function in NEK10-deficient cells (Figures 2 b-c and 5a-c). Therefore, the Y327F p53 298 mutant represents a unique hypomorphic variant of p53. 
This hypomorphic p53 response elicited by NEK10 loss was manifested by

300

301

302

303

304

305

306

307

308

309

310

311

312

313

314

315

316

317

318

319

320

321

differential reaction to DNA-damaging agents, such as cisplatin, where despite

comparable increases in p53 protein and p53 S15 levels in response to this genotoxic treatment, $N E K 10^{\Delta / \Delta}$ cells failed to induce expression of several p53 target genes (Figure 6a). Further, upon IR exposure, NEK10 $1 / \Delta$ cells displayed protracted kinetics of p53 and p21 induction (peaking at 8 hours) compared to a rapid induction and an early plateau in $\mathrm{NEK} 10^{+/+}$cells (0.5 hours) (Figure $6 \mathrm{~b}-\mathrm{c}$ ). The difference in induction kinetics of the p53 pathway likely accounts for the phenotypic results observed in cell survival and cell cycle arrest, discussed below [67-73]. While the changes in p53 tyrosine phosphorylation in response to genotoxic stress tracked with the previously wellcharacterized changes in p53 S15 phosphorylation and an increase in p53 transcriptional activity, Y327F mutation or NEK10 loss did not affect S15 phosphorylation. (Figure 6 a-b, $d-e$ ). This observation suggests that Y327 phosphorylation does not affect S15 phosphorylation and S15-mediated p53 stabilization, but likely acts to promote transactivation of p53 target genes.

The weakened p53 response in NEK10 $1 / \Delta$ cells likely contributed to their sensitivity to olaparib and cisplatin when compared to the $N E K 10^{+/+}$cells, presenting as increased apoptosis and decreased clonogenic survival (Figure 7). NEK10 $1 / \Delta$ cells failed to engage an effective G2/M arrest in response to cisplatin possibly due to the lack of induction of GADD45a, a key mediator of the G2/M checkpoint, contributing to accruement of deleterious DNA lesions and subsequent apoptosis (Figure 6a, 7e-f) [7476]. The observed NEK10-dependent differences in cell cycle arrest and apoptosis may indicate a selective response to genotoxic stressors, whereby the hypomorphic p53 
322 response fails to elicit cell cycle arrest, yet is able to support an apoptotic response.

323 Previous reports that the acetylation of p53 on Lys320 by PCAF leads to preferential

324 transactivation of cell cycle arrest genes over the apoptotic target genes [23-25]

325 supports the existence of post-translational modifications-driven fine-tuning of the p53

326 response.

Consistent with the diminution of p53 function in NEK10-deficient cells, analysis

of cancer genome data revealed associations of lowered NEK10 expression with worse

329 outcome in breast cancer, further suggestive of a tumour-suppressive function of NEK10, particularly in patients lacking somatic TP53 mutations (Figure 8a,b) [38-42]. In

331 contrast to breast cancer patients receiving other therapies, those with reduced expression of NEK10 displayed a beneficial response to radiation therapy, indicated by their grater overall survival (Figure 8d). The improvement in therapeutic response 334 appeared to require p53, as only tumours with WT TP53 showed the association 335 between NEK10 expression and radioresponse, reinforcing a p53-dependent function 336 for NEK10 in cancer (Figure 8e). Thus, patients with WT TP53 and reduced NEK10 337 expression represent a cohort that would likely benefit from radiotherapy, as lack of 338 such treatment in this group led to a striking increase in cancer recurrence.

340 activity through Y327 phosphorylation, with loss of NEK10 causing an impaired p53 341 response and a hypomorphic p53 phenotype. Recent studies have identified subsets of 342 breast cancers that are highly sensitive to genotoxic agents and radiation therapy, such 343 as those with DDR defects or genomic instability (i.e. BRCA1/2 deficiency or 
344 "BRCAness") [77-83]. Breast cancers with reduced NEK10 expression may constitute a

345 similar breast cancer subset that is exquisitely sensitive to genotoxic treatments and

346 radiotherapy due to an attenuated p53 response, rather than a direct defect in DNA

347 repair. Thus, low NEK10 expression levels represent a potential prognostic biomarker

348 for the already standard of care chemo/radiotherapeutic treatments for breast cancer.

349 Moreover, the yet to be developed NEK10 kinase inhibitors are predicted to act as

350 chemo- and radio-sensitizing agents in breast cancer treatment and improve patient

351 outcomes. 


\section{MATERIALS AND METHODS}

\section{Antibodies}

The following antibodies were purchased from Santa Cruz Biotechnology: Anti-GAPDH FL-335 (sc-25778), Anti-p53 FL-393 (sc6243), Anti-p-Tyr PY-99 (sc-7020), Anti-GADD45a C-4 (sc-6580). Anti-FLAG M2 (F3165) and Anti-FLAG M2 Agarose were from Sigma-Aldrich. Anti-p21 (556431) was from BD Pharmingen. Anti-MDM2 Ab-1 (OP46) was from Calbiochem. Anti-PUMA (NB500-261) was from Novus Biologicals. Anti-p53 S15 (9284) was from Cell Signalling Technology.

\section{Cell culture, transfections, viral infections and reagents}

HEK293T, HEK293T NEK10 $/ \Delta$, A549, A549 NEK10 $/ \Delta$, H1299. HCT116 p53+/+ and HCT116 p53\% cells and their derivatives were maintained in DMEM (Corning), supplemented with 10\% FBS (Wisent) and Pen/Strep (100 mg/ml, Hyclone).

Transient transfections of HEK293T cells were performed by using the calcium phosphate method. Transfection of other cell lines was achieved using PolyJet ${ }^{\mathrm{TM}}$ according to manufacturer's instructions.

All plasmids were constructed with the exception of the pLVX-3xFLAG-NEK10 series of constructs (Gift of Dr. Michael Yaffe). For expression in mammalian cells, NEK10 was cloned into 3xFLAG-CMV-7.1 NEK10, and p53 was cloned into pcDNA3His. For expression of recombinant proteins in bacterial cells, p53 was cloned into pGEX2TK. All point mutants were generated by using the QuickChange site-directed mutagenesis kit (Stratagene),

A549 NEK10 $1 / \Delta$ cells were engineered to express pLVX-FLAG, FLAG-NEK10 WT, FLAG-NEK10 D665N and FLAG-NEK10 I693P via lentiviral transduction. In short, 
375 transduction was performed with lentiviral particles in the presence of protamine sulfate

$376(5 \mu \mathrm{g} / \mathrm{mL})$ for 20 hours. Subsequent to transduction, cells were reseeded into 200

$377 \mu \mathrm{g} / \mathrm{mL}$ hygromycin (Sigma) and selected until negative control cells died (3-5 days).

378

379

380

381

382

383

384

385

386

387

388

389

390

391

392

393

394

395

396

397

\section{Cell lysis, immunoblotting and immunoprecipitations}

Unless indicated otherwise, for immunoblotting, cells were lysed in Laemmli sample buffer (50 mM Tris- $\mathrm{HCl} \mathrm{pH} 6.8,2 \%$ SDS, 10\% glycerol, 5\% $\beta$-mercaptoethanol), normalized for total protein content, resolved by SDS-PAGE, and transferred to PVDF membranes (Millipore). Membranes were blocked in 5\% BSA and probed with the indicated antibodies.

For immunoprecipitations, cells were lysed in RIPA buffer $(50 \mathrm{mM}$ Tris- $\mathrm{HCl} \mathrm{pH}$ 7.4, $150 \mathrm{mM} \mathrm{NaCl}, 1 \%$ Triton $\mathrm{X}-100,1 \%$ sodium deoxycholate, 0.1\% SDS, $1 \mathrm{mM}$ EDTA, supplemented with fresh $1 \mathrm{mM}$ dithiothreitol (DTT), $0.1 \mathrm{mM}$ sodium orthovanadate and a protease inhibitor cocktail (Sigma)) and sonicated followed by incubation on ice for 20 minutes. Insoluble material was removed by centrifugation at $15,000 \times \mathrm{g}$ for $15 \mathrm{~min}$ at $4^{\circ} \mathrm{C}$. Samples were then equalized using the Bradford protein assay (Biorad), and incubated with the indicated antibody. Immunoprecipitations were performed by gentle end over end rotation for 3 hours, followed by incubation with protein A/G-sepharose beads for 45 minutes, and then immune complexes were washed four times in cold RIPA buffer and resuspended in Laemmli loading buffer.

\section{Protein half-life determination}

Cells were incubated with $200 \mu \mathrm{g} / \mathrm{mL}$ of cyclohexamide (Sigma-Aldrich) for the indicated times and lysed in Laemmli buffer loading buffer. Protein levels were detected by immunoblotting. 
assay as described in [84].

Cells were then washed twice with PBS and fixed and dyed with a solution containing: CellCounter plugin.

RNA isolation, reverse transcription and quantitative real time PCR (RT-

\section{qPCR) analysis}

411 DNAaway RNA Miniprep kit (Bio Basic). Reverse transcription to generate cDNAs was

412 performed using the qScript cDNA SuperMix (Quantabio). Quantitative real-time PCR 413 analysis was performed using PerfeCTa SYBR Supermix with 20 ng of cDNA per 414 reaction and $200 \mathrm{nM}$ of the following specific primers:

\begin{tabular}{|l|l|l|}
\hline Target & Forward & Reverse \\
\hline Gapdh & AGCCTAAGATCATCAGCAATG & ATGGACTGTGGTCATGAGTCCTT \\
\hline p21 & AGGCACCGAGGCACTCAGAG & AGTGGTAGAAATCTGTCATGCTG \\
\hline p53 & ATGGAGGAG CCG CAG TCA GAT & GCAGCGCCT CACAACCTCCGTC \\
\hline Mdm2 & AAGAGACCCTGGTTAGACCAAAGC & TTTCTTCTGTCTCACTAATTGCTCT \\
\hline Gadd45 $\alpha$ & TGCTCAGCAAAGCCCTGAGT & GCTTGGCCGCTTCGTACA \\
\hline Bax & TGGAGCTGCAGAGGATGATTG & GAAGTTGCCGTCAGAAAACATG \\
\hline
\end{tabular}


416 Quantitative real-time PCR was performed on the Roche LightCycler 480, and relative

417 mRNA expression was calculated using the $2^{-\Delta \Delta C t}$ method using GAPDH as a reference 418 gene [85].

\section{Cell cycle analysis by flow cytometry}

For both methods of cell cycle analysis, cells were seeded into $6 \mathrm{~cm}$ plates,

421 treated as indicated, trypsinized, and fixed with ice cold $70 \%$ ethanol $\left(-20^{\circ} \mathrm{C}\right)$ with gentle

422 vortexing. Cells were then allowed to fix on ice for one hour.

For total DNA content analysis for cell cycle distribution, samples were washed

424 twice with PBS and stained with $50 \mu \mathrm{g} / \mathrm{mL}$ propidium iodide and $20 \mu \mathrm{g} / \mathrm{mL}$ RNAse A in

425 PBS $+0.1 \%$ Triton X-100. Stained cells were analysed on a FACSCanto flow cytometer

426 (BD Biosciences) and CellQuest software (BD Immunocytometry Systems). $10^{4}$ events

427 were analyzed for each sample on FlowJo.

For the quantification of mitotic cells, indirect immunofluorescence was used on ethanol fixed cells using an anti-phospho-H3 (Ser10) antibody (Millipore). Briefly, cells were washed twice with PBS, and permeabilized with $0.25 \%$ Triton $X-100$ and

431 incubated on ice for 15 minutes. Cells were washed twice with PBS $+1 \%$ BSA and 432 incubated with $0.25 \mu \mathrm{g}$ anti-phospho-H3 (Ser10) antibody with 1\% BSA for 1 hour at 433 room temperature. Cells were then incubated in goat anti-mouse IgG conjugated to 434 Alexa488 (1:300 dilution) with 1\% BSA at room temperature for 30 minutes under light 435 protection. Cells were then counterstained with a DNA content stain consisting of 50 $436 \mu \mathrm{g} / \mathrm{mL}$ propidium iodide and $20 \mu \mathrm{g} / \mathrm{mL}$ RNAse A in PBS. Stained cells were analysed on 437 a FACSCanto flow cytometer (BD Biosciences) and CellQuest software (BD 
438 Immunocytometry Systems). Twenty thousand events were analyzed for each sample 439 on FlowJo.

\section{Annexin V/Propidium lodide assay for apoptosis}

For Annexin V/PI assays, cells were evaluated for apoptosis by flow cytometry

442 according to the manufacturer's protocol (BD Pharmingen, San Diego, CA, USA).

443 Briefly, cells were trypsinized, washed with PBS and $2 \times 10^{5}$ cells were stained with $5 \mu \mathrm{L}$

444 of Annexin V-FITC and $10 \mu \mathrm{L}$ of $50 \mathrm{ng} / \mathrm{mL}$ of propidium iodide in $200 \mu \mathrm{L}$ binding buffer

445 (10 mM HEPES, pH 7.4, $140 \mathrm{mM} \mathrm{NaCl,} 2.5 \mathrm{mM} \mathrm{CaCl}_{2}$ ) for 15 minutes at room 446 temperature in the dark. The apoptotic cells were determined using a FACSCanto flow

447 cytometer (BD Biosciences) and CellQuest software (BD Immunocytometry Systems).

448 Ten thousand events were analyzed for each sample on FlowJo.

\section{Bacterial protein purification}

GST-p53 and GST-p53 Y327F were produced in BL21 E.coli cells. Single

451 colonies of transformed bacteria were inoculated as starter cultures and grown

452 overnight at $37^{\circ} \mathrm{C}$ with gentle agitation. Starter cultures were diluted into large scale

453 production cultures to an OD600 of $0.05-0.1$. Production cultures were allowed to grow

454 until an $\mathrm{OD}_{600}$ of 0.5 had been reached, subsequent to which cultures were incubated

455 with $0.5 \mathrm{mM}$ of IPTG for 4 hours. Cells were pelleted at $6000 x \mathrm{x}$ for 15 min, followed by

456 snap freezing in liquid nitrogen. Cells were then thawed in a $37^{\circ} \mathrm{C}$ water bath and lysed

457 with PBS $+1 \%$ Triton X-100 + lysozyme. Cells were sonicated in 15 second pulses,

458 followed by 15 seconds on ice three times, and then left on ice for 30 minutes. Insoluble

459 material was removed via centrifugation at 15,000xg for 15 minutes. The supernatant 
461 were then washed three times with lysis buffer, and incubated with elution buffer (10

$462 \mathrm{mM}$ reduced glutathione, $50 \mathrm{mM}$ Tris- $\mathrm{HCl} \mathrm{pH} 7.6,150 \mathrm{mM} \mathrm{NaCl}$ ) three times for 10

463 mines. Eluted fractions were pooled and protein amount and purity was determined via

464 SDS-PAGE Coomassie staining.

465

In Vitro Kinase Assays

466

Kinase assays were performed by the incubation of $100-200 \mathrm{ng}$ of purified

$467 \mathrm{NEK} 10$ at $30^{\circ} \mathrm{C}$ for 30 minutes in kinase assay buffer supplemented with $5 \mu \mathrm{Ci}\left[\mathrm{Y}^{-32} \mathrm{P}\right]$

468 ATP, $20 \mu \mathrm{M}$ ATP and $1 \mu \mathrm{g}$ of GST-p53 or GST-p53 Y327F. Reactions were terminated 469 using electrophoresis buffer followed by boiling for 5 minutes. Samples were resolved

470 with SDS-PAGE, and imaged on a Typhoon Imager (GE Healthcare Lifesciences).

471 Relative activity was determined using densitometry on ImageJ.

To determine the proportion of cells with active DNA synthesis, we used a 474 modified EdU pulse labeling protocol that utilizes Click chemistry. Briefly, cells were 475 grown and pulse labeled with $10 \mu \mathrm{M}$ EdU (Setareh Biotech) for 2 hours at $37^{\circ} \mathrm{C}$ with $5 \%$ $476 \mathrm{CO}_{2}$. Cells were then trypsinized and fixed with $4 \%$ paraformaldehyde, permeabilized 477 with $0.1 \%$ Triton X-100, washed with PBS $+1 \%$ BSA. Permeabilized cells were dyed 478 with a Click labelling dye (8 $\mu \mathrm{M}$ FAM-Azide 488 (Lumiprobe), 2 mM CuSO 4,20 mg/mL 479 ascorbic acid) for 30 minutes in the dark at room temperature. 10,000 cells were 480 counted and analysed using a FACSCanto flow cytometer (BD Biosciences) and 481 CellQuest software (BD Immunocytometry Systems). 


\section{Oligomerization Assay}

485

Cells were treated as indicated and lysed with a buffer containing: $25 \mathrm{mM}$ Hepes

$486 \mathrm{pH} 7.5,150 \mathrm{mM} \mathrm{NaCl}$, and 1\% NP-40, supplemented with fresh $1 \mathrm{mM}$ dithiothreitol

487 (DTT), $0.1 \mathrm{mM}$ sodium orthovanadate and a protease inhibitor cocktail (Sigma). Lysates

488 were incubated on ice for $20 \mathrm{~min}$, and insoluble material was removed by centrifugation

489 at $15,000 \times \mathrm{g}$ for $15 \mathrm{~min}$ at $4^{\circ} \mathrm{C}$. Samples were then equalized using the Bradford 490 protein assay, and treated with $0.025 \%$ Glutaraldehyde for 30 minutes on ice. The 491 glutaraldehyde was quenched with the addition of $100 \mathrm{mM}$ Glycine $\mathrm{pH} 2.5$.

\section{Bioinformatics Analysis}

RNASeq V2 and clinical data from The Cancer Genome Atlas (TCGA) Breast

494 datasets downloaded from the UCSC XENA platform were used to generate Kaplan495 Meier survival curves (xena.ucsc.edu) [86]. Median expression of NEK10 was used to 496 divide the "NEK10 High" and "NEK10 Low" groups. 


\section{REFERENCES}

1. Menendez, D., A. Inga, and M.A. Resnick, The expanding universe of p53 targets. Nat Rev Cancer, 2009. 9(10): p. 724-37.

2. Kastenhuber, E.R. and S.W. Lowe, Putting p53 in Context. Cell, 2017. 170(6): p. 10621078.

3. Horn, H.F. and K.H. Vousden, Coping with stress: multiple ways to activate p53. Oncogene, 2007. 26(9): p. 1306-16.

4. Pappas, K., et al., p53 Maintains Baseline Expression of Multiple Tumor Suppressor Genes. Mol Cancer Res, 2017. 15(8): p. 1051-1062.

5. Allen, M.A., et al., Global analysis of p53-regulated transcription identifies its direct targets and unexpected regulatory mechanisms. Elife, 2014. 3: p. e02200.

6. Fischer, M., Census and evaluation of p53 target genes. Oncogene, 2017. 36(28): p. 3943-3956.

7. McGranahan, N. and C. Swanton, Clonal Heterogeneity and Tumor Evolution: Past, Present, and the Future. Cell, 2017. 168(4): p. 613-628.

8. Malkin, D., Li-fraumeni syndrome. Genes Cancer, 2011. 2(4): p. 475-84.

9. Riley, T., et al., Transcriptional control of human p53-regulated genes. Nat Rev Mol Cell Biol, 2008. 9(5): p. 402-12.

10. Huang, L.C., K.C. Clarkin, and G.M. Wahl, Sensitivity and selectivity of the DNA damage sensor responsible for activating p53-dependent G1 arrest. Proc Natl Acad Sci U S A, 1996. 93(10): p. 4827-32.

11. Kumari, R., S. Kohli, and S. Das, p53 regulation upon genotoxic stress: intricacies and complexities. Mol Cell Oncol, 2014. 1(3): p. e969653.

12. Haupt, Y., et al., Mdm2 promotes the rapid degradation of p53. Nature, 1997. 387(6630): p. 296-9.

13. Brooks, C.L. and W. Gu, p53 ubiquitination: Mdm2 and beyond. Mol Cell, 2006. 21(3): p. 307-15.

14. Canman, C.E., et al., Activation of the ATM kinase by ionizing radiation and phosphorylation of p53. Science, 1998. 281(5383): p. 1677-9.

15. Stommel, J.M. and G.M. Wahl, Accelerated MDM2 auto-degradation induced by DNAdamage kinases is required for p53 activation. EMBO J, 2004. 23(7): p. 1547-56.

16. Tibbetts, R.S., et al., A role for ATR in the DNA damage-induced phosphorylation of p53. Genes Dev, 1999. 13(2): p. 152-7.

17. Schon, O., et al., Molecular mechanism of the interaction between MDM2 and p53. J Mol Biol, 2002. 323(3): p. 491-501.

18. Banin, S., et al., Enhanced phosphorylation of p53 by ATM in response to DNA damage. Science, 1998. 281(5383): p. 1674-7.

19. Tang, Y., et al., Acetylation is indispensable for p53 activation. Cell, 2008. 133(4): p. 612-26.

20. Sykes, S.M., et al., Acetylation of the p53 DNA-binding domain regulates apoptosis induction. Mol Cell, 2006. 24(6): p. 841-51.

21. Tang, Y., et al., Tip60-dependent acetylation of p53 modulates the decision between cell-cycle arrest and apoptosis. Mol Cell, 2006. 24(6): p. 827-39.

22. Sykes, S.M., et al., Acetylation of the DNA binding domain regulates transcriptionindependent apoptosis by p53. J Biol Chem, 2009. 284(30): p. 20197-205.

23. Chao, C., et al., Acetylation of mouse p53 at lysine 317 negatively regulates $p 53$ apoptotic activities after DNA damage. Mol Cell Biol, 2006. 26(18): p. 6859-69.

24. Liu, L., et al., p53 sites acetylated in vitro by PCAF and p300 are acetylated in vivo in response to DNA damage. Mol Cell Biol, 1999. 19(2): p. 1202-9. 
25. Knights, C.D., et al., Distinct p53 acetylation cassettes differentially influence geneexpression patterns and cell fate. J Cell Biol, 2006. 173(4): p. 533-44.

26. Jansson, M., et al., Arginine methylation regulates the p53 response. Nat Cell Biol, 2008. 10(12): p. 1431-9.

27. Chen, Y., et al., Never-in-mitosis related kinase 1 functions in DNA damage response and checkpoint control. Cell Cycle, 2008. 7(20): p. 3194-201.

28. Chen, Y., et al., Nek1 kinase functions in DNA damage response and checkpoint control through a pathway independent of ATM and ATR. Cell Cycle, 2011. 10(4): p. 655-63.

29. Sabir, S.R., et al., Loss of Nek11 Prevents G2/M Arrest and Promotes Cell Death in HCT116 Colorectal Cancer Cells Exposed to Therapeutic DNA Damaging Agents. PLoS One, 2015. 10(10): p. e0140975.

30. Melixetian, M., et al., NEK11 regulates CDC25A degradation and the IR-induced G2/M checkpoint. Nat Cell Biol, 2009. 11(10): p. 1247-53.

31. Noguchi, K., et al., Nek11, a new member of the NIMA family of kinases, involved in DNA replication and genotoxic stress responses. J Biol Chem, 2002. 277(42): p. 3965565.

32. Fletcher, L., et al., Inhibition of centrosome separation after DNA damage: a role for Nek2. Radiat Res, 2004. 162(2): p. 128-35.

33. Mi, J., et al., Protein phosphatase-1alpha regulates centrosome splitting through Nek2. Cancer Res, 2007. 67(3): p. 1082-9.

34. Lee, M.Y., et al., Nek6 is involved in G2/M phase cell cycle arrest through DNA damageinduced phosphorylation. Cell Cycle, 2008. 7(17): p. 2705-9.

35. Choi, H.J., et al., NEK8 links the ATR-regulated replication stress response and S phase CDK activity to renal ciliopathies. Mol Cell, 2013. 51(4): p. 423-39.

36. Abeyta, A., et al., NEK8 regulates DNA damage-induced RAD51 foci formation and replication fork protection. Cell Cycle, 2017. 16(4): p. 335-347.

37. Smith, S.C., et al., A gemcitabine sensitivity screen identifies a role for NEK9 in the replication stress response. Nucleic Acids Res, 2014. 42(18): p. 11517-27.

38. Moniz, L.S. and V. Stambolic, Nek10 mediates G2/M cell cycle arrest and MEK autoactivation in response to UV irradiation. Mol Cell Biol, 2011. 31(1): p. 30-42.

39. Forbes, S.A., et al., COSMIC: somatic cancer genetics at high-resolution. Nucleic Acids Res, 2017. 45(D1): p. D777-D783.

40. Gao, J., et al., Integrative analysis of complex cancer genomics and clinical profiles using the cBioPortal. Sci Signal, 2013. 6(269): p. pl1.

41. Cerami, E., et al., The cBio cancer genomics portal: an open platform for exploring multidimensional cancer genomics data. Cancer Discov, 2012. 2(5): p. 401-4.

42. Ahmed, S., et al., Newly discovered breast cancer susceptibility loci on 3p24 and 17q23.2. Nat Genet, 2009. 41(5): p. 585-90.

43. Mendoza, M.C., E.E. Er, and J. Blenis, The Ras-ERK and PI3K-mTOR pathways: crosstalk and compensation. Trends Biochem Sci, 2011. 36(6): p. 320-8.

44. Cazzalini, O., et al., Multiple roles of the cell cycle inhibitor p21(CDKN1A) in the DNA damage response. Mutat Res, 2010. 704(1-3): p. 12-20.

45. Besson, A., S.F. Dowdy, and J.M. Roberts, CDK inhibitors: cell cycle regulators and beyond. Dev Cell, 2008. 14(2): p. 159-69.

46. Giono, L.E. and J.J. Manfredi, The p53 tumor suppressor participates in multiple cell cycle checkpoints. J Cell Physiol, 2006. 209(1): p. 13-20.

47. Junttila, M.R. and G.I. Evan, p53--a Jack of all trades but master of none. Nat Rev Cancer, 2009. 9(11): p. 821-9.

48. Moniz, L.S., Characterization of NimA-related kinase 10 (NEK10): A role in checkpoint control. 2010, University of Toronto, 2010. p. 178 leaves. 
631

632

633

634

635

636

637

638

639

640

641

642

643

644

645

646

49. Huang, Y.F. and D.V. Bulavin, Oncogene-mediated regulation of p53 ISGylation and functions. Oncotarget, 2014. 5(14): p. 5808-18.

50. Tsai, C.F., et al., Large-scale determination of absolute phosphorylation stoichiometries in human cells by motif-targeting quantitative proteomics. Nat Commun, 2015. 6: $\mathrm{p}$. 6622.

51. Bai, Y., et al., Phosphoproteomics identifies driver tyrosine kinases in sarcoma cell lines and tumors. Cancer Res, 2012. 72(10): p. 2501-11.

52. Kawaguchi, T., et al., The relationship among p53 oligomer formation, structure and transcriptional activity using a comprehensive missense mutation library. Oncogene, 2005. 24(46): p. 6976-81.

53. Yakovlev, V.A., et al., Nitration of the tumor suppressor protein p53 at tyrosine 327 promotes p53 oligomerization and activation. Biochemistry, 2010. 49(25): p. 5331-9.

54. Chong, L.T., et al., Kinetic computational alanine scanning: application to p53 oligomerization. J Mol Biol, 2006. 357(3): p. 1039-49.

55. Davies, $\mathrm{H}$., et al., Somatic mutations of the protein kinase gene family in human lung cancer. Cancer Res, 2005. 65(17): p. 7591-5.

56. Greenman, C., et al., Patterns of somatic mutation in human cancer genomes. Nature, 2007. 446(7132): p. 153-8.

57. Ebctcg, et al., Effect of radiotherapy after mastectomy and axillary surgery on 10-year recurrence and 20-year breast cancer mortality: meta-analysis of individual patient data for 8135 women in 22 randomised trials. Lancet, 2014. 383(9935): p. 2127-35.

58. Early Breast Cancer Trialists' Collaborative, G., et al., Effect of radiotherapy after breastconserving surgery on 10-year recurrence and 15-year breast cancer death: metaanalysis of individual patient data for 10,801 women in 17 randomised trials. Lancet, 2011. 378(9804): p. 1707-16.

59. Lakin, N.D. and S.P. Jackson, Regulation of p53 in response to DNA damage. Oncogene, 1999. 18(53): p. 7644-55.

60. Meek, D.W., The p53 response to DNA damage. DNA Repair (Amst), 2004. 3(8-9): p. 1049-56.

61. Jee, H.J., et al., Nek6 overexpression antagonizes p53-induced senescence in human cancer cells. Cell Cycle, 2010. 9(23): p. 4703-10.

62. Salem, H., et al., Nek7 kinase targeting leads to early mortality, cytokinesis disturbance and polyploidy. Oncogene, 2010. 29(28): p. 4046-57.

63. Moniz, L., et al., Nek family of kinases in cell cycle, checkpoint control and cancer. Cell Div, 2011. 6: p. 18.

64. Wang, S. and W.S. El-Deiry, p73 or p53 directly regulates human $p 53$ transcription to maintain cell cycle checkpoints. Cancer Res, 2006. 66(14): p. 6982-9.

65. Hudson, J.M., R. Frade, and M. Bar-Eli, Wild-type $p 53$ regulates its own transcription in a cell-type specific manner. DNA Cell Biol, 1995. 14(9): p. 759-66.

66. Deffie, A., et al., The tumor suppressor p53 regulates its own transcription. Mol Cell Biol, 1993. 13(6): p. 3415-23.

67. Purvis, J.E., et al., p53 dynamics control cell fate. Science, 2012. 336(6087): p. 1440-4.

68. Chen, X., et al., DNA damage strength modulates a bimodal switch of p53 dynamics for cell-fate control. BMC Biol, 2013. 11: p. 73.

69. Stewart-Ornstein, J. and G. Lahav, p53 dynamics in response to DNA damage vary across cell lines and are shaped by efficiency of DNA repair and activity of the kinase ATM. Sci Signal, 2017. 10(476).

70. Espinosa, J.M., R.E. Verdun, and B.M. Emerson, p53 functions through stress- and promoter-specific recruitment of transcription initiation components before and after DNA damage. Mol Cell, 2003. 12(4): p. 1015-27. 
647 71. Morachis, J.M., C.M. Murawsky, and B.M. Emerson, Regulation of the p53

648

649

650

651

652

653

654

655

656

657

658

659

660

661

662

663

664

665

666

667

668

669

670

671

672

673

674

675

676

677

678

679

680

681

682 transcriptional response by structurally diverse core promoters. Genes Dev, 2010. 24(2): p. 135-47.

72. Batchelor, E., et al., Stimulus-dependent dynamics of p53 in single cells. Mol Syst Biol, 2011. 7: p. 488.

73. Brady, C.A., et al., Distinct p53 transcriptional programs dictate acute DNA-damage responses and tumor suppression. Cell, 2011. 145(4): p. 571-83.

74. Jin, S., et al., GADD45-induced cell cycle G2-M arrest associates with altered subcellular distribution of cyclin B1 and is independent of p38 kinase activity. Oncogene, 2002. 21(57): p. 8696-704.

75. Wang, X.W., et al., GADD45 induction of a G2/M cell cycle checkpoint. Proc Natl Acad Sci U S A, 1999. 96(7): p. 3706-11.

76. Taylor, W.R. and G.R. Stark, Regulation of the G2/M transition by p53. Oncogene, 2001. 20(15): p. 1803-15.

77. Lord, C.J. and A. Ashworth, BRCAness revisited. Nat Rev Cancer, 2016. 16(2): p. 11020.

78. Tutt, A., et al., Carboplatin in BRCA1/2-mutated and triple-negative breast cancer BRCAness subgroups: the TNT Trial. Nat Med, 2018. 24(5): p. 628-637.

79. De Summa, S., et al., BRCAness: a deeper insight into basal-like breast tumors. Ann Oncol, 2013. 24 Suppl 8: p. viii13-viii21.

80. Shah, S.P., et al., The clonal and mutational evolution spectrum of primary triplenegative breast cancers. Nature, 2012. 486(7403): p. 395-9.

81. Curtis, C., et al., The genomic and transcriptomic architecture of 2,000 breast tumours reveals novel subgroups. Nature, 2012. 486(7403): p. 346-52.

82. Burstein, M.D., et al., Comprehensive genomic analysis identifies novel subtypes and targets of triple-negative breast cancer. Clin Cancer Res, 2015. 21(7): p. 1688-98.

83. Lehmann, B.D., et al., Refinement of Triple-Negative Breast Cancer Molecular Subtypes: Implications for Neoadjuvant Chemotherapy Selection. PLoS One, 2016. 11(6): p. e0157368.

84. Vichai, V. and K. Kirtikara, Sulforhodamine B colorimetric assay for cytotoxicity screening. Nat Protoc, 2006. 1(3): p. 1112-6.

85. Schmittgen, T.D. and K.J. Livak, Analyzing real-time PCR data by the comparative $C(T)$ method. Nat Protoc, 2008. 3(6): p. 1101-8.

86. Goldman, M., et al., The UCSC Xena Platform for cancer genomics data visualization and interpretation. bioRxiv, 2018. 


\section{FIGURE LEGENDS}

685 Figure 1. NEK10 loss leads to an increase in cellular proliferation and DNA replication.

A) Proliferation curve of A549 NEK10+/+ and A549 NEK10 ${ }^{\Delta / \Delta}$ cells measured using SRB assay over a 72-hour time period. Relative growth was calculated relative to the absorbance at $t=0$ for each cell line $(p<0.002$, $t$ test, $n=3$, bars represent SEM). B-C) Colony forming assay of $N E K 10^{+/+}$and NEK $10^{\Delta / \Delta}$ A549 cells. 100 cells of each genotype were seeded and their plating efficiency determined $(p<0.05$, t test, $n=3$, bars represent SEM). D) Cell cycle distribution was determined using propidium iodide staining for total DNA content. G1, S and G2 fractions were distinguished using FlowJo. E) NEK10+/+ and performed to quantify the proportion of cells with active DNA replication. F) Asynchronous cells were stained with a phospho-H3 (Ser10) antibody to determine the proportion of mitotic cells. ( $p<0.01$, $t$ test, $n=3$, bars represent SEM).

Figure 2. NEK10 status modulates the expression of p53-responsive genes.

A)-B) Immunoblot of A549 NEK10+/+ and NEK10 $1 / \Delta$ cells for the expression of the indicated proteins. C) Cyclohexamide pulse chase experiment to determine half-life of

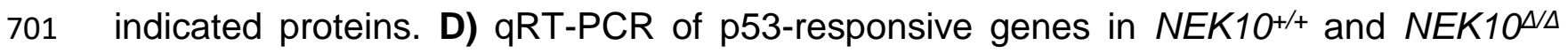
cells reconstituted with indicated lentiviral constructs. 
706

707

708

709

710

711

712

713

714

715

716

717

718

719

720

721

722

723

724

725

726

727

728

A). Proliferation measurement of $N E K 10^{\Delta / \Delta}$ A549 cells reconstituted with the indicated constructs $\left(\mathrm{p}<0.01\right.$, $\mathrm{t}$ test, $\mathrm{n}=3$, bars represent SEM). B) Immunoblot of $N E K 10^{\Delta / \Delta} \mathrm{A} 549$ cells reconstituted with the indicated constructs. C) qRT-PCR of p53-responsive genes in NEK10 $10^{\Delta}$ A549 cells reconstituted with the indicated constructs. mRNA expression levels are expressed relative to the expression levels in pLVX-NEK10 $1 / \Delta$ A549 cells $(p<0.05$, t test, $n=3$, bars represent SEM).

\section{Figure 4. NEK10 phosphorylates p53 on Y327 in vitro.}

A) Radioactive in vitro kinase assay performed using purified FLAG-NEK10 WT and kinase dead FLAG-NEK10 (A546F) incubated with GST alone or GST-p53. B) HEK293T cells transfected with the indicated constructs were lysed under denaturing conditions and tyrosine phosphorylated proteins were immunoprecipitated. The amount of pY-p53 was determined by anti-p53 immunoblotting. C) Schematic representation of p53 domain organization highlighting the location of Y327 with the relevant domains indicated. D) Radioactive in vitro kinase assay performed using purified FLAG-NEK10 WT and a peptide centered on Y327. Incorporated radioactive ${ }^{32} \mathrm{P}$ was quantified via liquid scintillation at the indicated time points. E) Quantification of relative rates of phosphate transfer for WT peptide and phosphoacceptor site mutants $(p<0.05$, t test, $\mathrm{n}=3$, bars represent SEM). F) Radioactive in vitro kinase assay performed using purified FLAG-NEK10 WT and the indicated GST-p53 constructs. G) Quantification of relative phosphate transfer $(p<0.05$, t test, $n=3$, bars represent SEM). H) Indicated p53 constructs were transfected into NEK10+/+ and NEK10 $0^{\Delta / \Delta}$ A549 cells and the phosphotyrosine-containing proteins were immnoprecipitated. The amount of pY-p53 was determined by anti-p53 immunoblotting. 
Figure 5. Mutation of p53-Y327 attenuates the expression of $\mathrm{p} 53$ target genes.

A) qRT-PCR of p53 responsive genes in HCT116 $p 53^{-/-}$cells reconstituted with

731 indicated constructs to determine relative expression levels compared to WT-p53 $\left({ }^{*}=\right.$ $\mathrm{p}<0.05,{ }^{* *}=\mathrm{p}<0.01,{ }^{* * *}=\mathrm{p}<0.001, \mathrm{t}$ test, $\mathrm{n}=3$, bars represent SEM). B) Heatmap of $\mathrm{qRT}$ -

PCR of p53 responsive genes C) Immunoblot of HCT116 p53\%- cells reconstituted with indicated His-p53 constructs. Quantifications of the expression levels of p21 relative to the cells overexpressing WT-p53 are indicated. D) Immunoblot of H1299 cells reconstituted with the indicated variants of FLAG-NEK10 and His-p53. Quantifications of expression levels of p21 relative to cells overexpressing both FLAG and WT-p53 are

738 indicated.

Figure 6. NEK10 modulates the expression of p53 responsive genes is response to genotoxic agents.

A) $\mathrm{NEK} 10^{+/+}$and $\mathrm{NEK} 10^{\Delta / \Delta} \mathrm{A} 549$ cells were exposed to $5 \mu \mathrm{M}$ of cisplatin and were lysed 20 hours after treatment B) NEK10+/+ and NEK10 $1 / \Delta$ A549 cells were exposed to 5 Gy of IR and were lysed at the indicated time points after treatment. C) Quantifications of the

744 expression levels of $\mathrm{p} 21$ relative to the $\mathrm{p} 21$ levels of $N E K 10^{+/+}$cells at $T_{0}(\mathrm{n}=3$, bars 745 represent $\left.\mathrm{SEM},{ }^{*}=\mathrm{p}<0.005\right)$. D) $\mathrm{H} 1299$ cells transfected with the indicated constructs 746 were treated with 5 Gy of ionizing radiation and lysed at the indicated timepoints under 747 denaturing conditions and tyrosine phosphorylated proteins were immnoprecipitated.

748 The amount of pY-p53 was determined by anti-p53 immunoblotting. E) H1299 cells 749 transfected with the indicated constructs were lysed under denaturing conditions in 750 response to IR and immunoblots were performed to monitor the expression of the 
751 indicated proteins. Quantifications of the expression levels of p21 relative to the 752 untreated cells are indicated.

753 Figure 7. NEK10 loss sensitizes cells to chemotherapeutic agents.

754 A)-B) $N E K 10^{+/+}$and $N E K 10^{\Delta / \Delta}$ A549 cells were treated with the increasing doses of 755 olaparib or cisplatin and assessed for clonogenic survival 10-12 days after treatment. 756 Graph represents percent of cells that survive after treatment compared to untreated 757 control $(p<0.005$, t test, $n=3$, bars represent SEM). C) Cells were treated with $5 \mu \mathrm{M}$ of 758 cisplatin overnight and allowed to recover for $24 \mathrm{H}$ prior to being analysed for DNA 759 content with propidium iodide. D) Quantification of G2 populations for cisplatin treated 760 cells as an indicator of $\mathrm{G} 2 / \mathrm{M}$ arrest ( $p<0.01$, $t$ test, $n=4$, bars represent $S E M)$. E) Cells 761 were treated with $5 \mu \mathrm{M}$ cisplatin for 20 hours and then assessed for proportion of sub762 G1 cells, an indicator of cell death, at the indicated time points after treatment $(p<0.05, \mathrm{t}$ 763 test, $n=3$, bars represent SEM). F) Cells were treated with indicated doses of cisplatin 764 and assessed for apoptosis with Annexin V/propidium iodide staining 24 hours after 765 overnight cisplatin treatment.

Figure 8. Reduced NEK10 expression correlates with poor patient survival.

A) Kaplan-Meier curve showing overall survival analysis in patients with high and low expression of NEK10 mRNA from TCGA breast cancer dataset, with patients dichotomized into High NEK10 and Low NEK10 groups based on the median mRNA expression of NEK10 B) Kaplan-Meier curve showing overall survival in patients with

771 either WT TP53 or MUT TP53 relative to NEK10 mRNA expression C) Kaplan-Meier 772 curve showing overall survival analysis in patients that had either received radiotherapy 
773 (Radiation $\mathrm{Tx}$ ), or did not receive radiation as part of their treatment regimen (No

774 Radiation Tx) D) Kaplan-Meier curve showing overall survival in patients with either

775 High or Low levels of NEK10 expression in the context of radiation treatment. E)

776 Kaplan-Meier curve showing overall survival in patients with either WT TP53 or MUT

777 TP53 relative to NEK10 mRNA expression in the context of radiation treatment. The p-

778 values indicated were calculated using log rank analysis as indicated, and the number

779 of patients in each group is also indicated.

\section{SUPPLEMENTAL FIGURES}

782

Figure S1. CRISPR-Cas9-mediated NEK10 deletion strategy.

A) i. Deletion of NEK10 exon 24, encoding the critical DFG kinase domain motif, was engineered using paired sgRNA-guided Cas9 nickases to introduce cuts in intronic sequences upstream and downstream of the targeted exon. The specific sequences targeted by the sgRNAs are represented in blue and the predicted cut sites by green arrowheads. ii. The loss of exon 24 generates a frameshift mutation that introduces a

791 initially established by means of genomic PCR using primers (red arrows) external to 792 the predicted cut sites (green arrowheads). The predicted PCR product sizes and a 793 representative gel are shown. C) Two RT-PCR reactions were utilized as additional 794 confirmation of exon 24 deletion. The first reaction set (PCR\#2) employed primers (red 795 arrows) upstream and downstream of the targeted exon such that the loss of exon 24 
796 could be detected by a reduction in the size of the PCR product. The second reaction

797 set (PCR\#3) employed an upstream primer within the deleted exon enabling the loss of

798 exon 24 to be established by the absence of PCR product. The predicted PCR product

799 sizes and a representative gel are shown.

800

801 Figure S2. 1693 in the activation loop is required for tyrosine kinase activity.

802 A) The catalytic and activation loops of NEK kinase family members were aligned with 803 CLUSTAL Omega, residues unique to NEK10 are indicated with arrows. B) The 804 catalytic and activation loops of NEK10 homologues from the indicated species were 805 aligned using CLUSTAL Omega to determine the degree of conservation of unique 806 amino acids. C) Purified NEK10 and activation loop mutants were analysed for their 807 ability to autophosphorylate on tyrosines via radioactive kinase assay for the total 808 kinase activity and via western blot for tyrosine activity. D) Summary table indicating 809 substrate specificity for NEK10 mutants.

811 Figure S3. Y327F mutation does not affect p53 oligomerization.

813 HCT116 p53 $^{--}$cells expressing the indicated constructs were lysed and lysates were 814 treated with $0.025 \%$ glutaraldehyde to cross link proteins and immunoblotted to assess 815 the degree of p53 oligomerization. 
bioRxiv preprint doi: https://doi.org/10.1101/516971; this version posted January 10, 2019. The copyright holder for this preprint (which was not certified by peer review) is the author/funder, who has granted bioRxiv a license to display the preprint in perpetuity. It is made available under

A

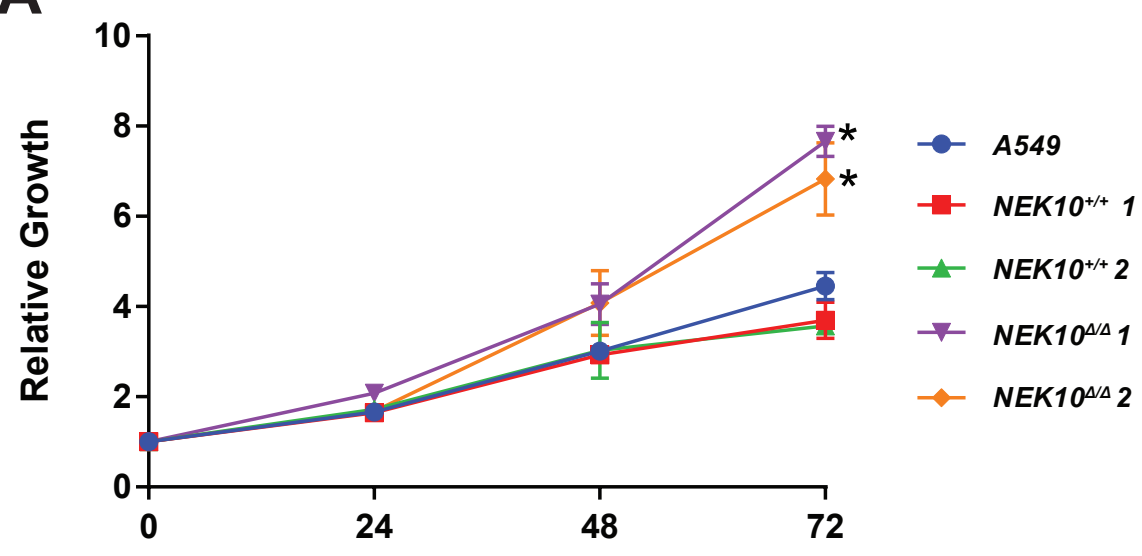

C

Time (Hr)

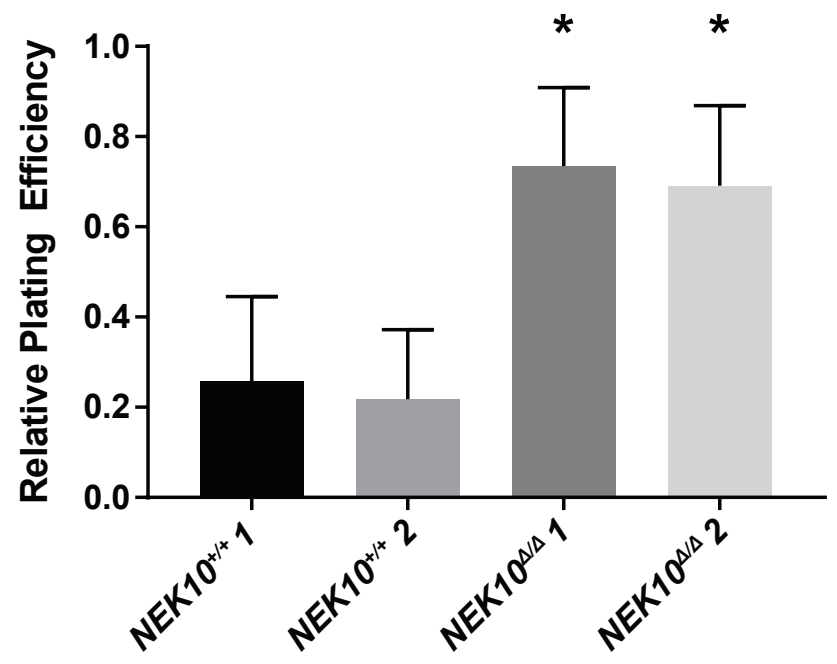

E

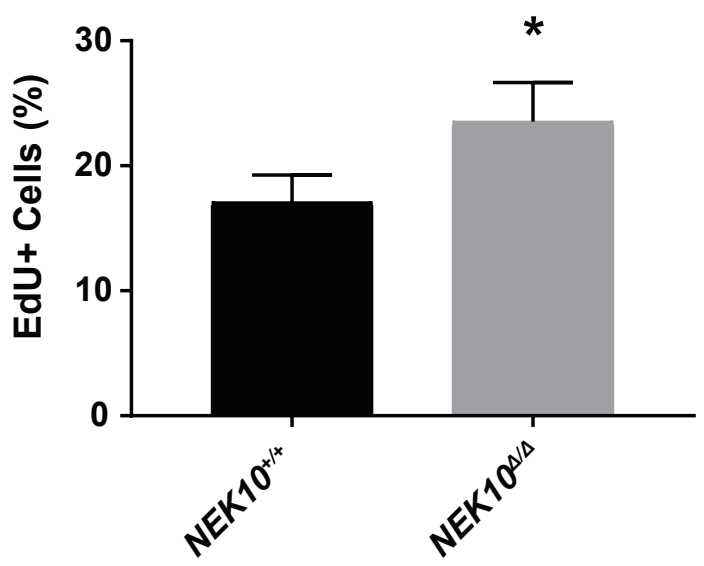

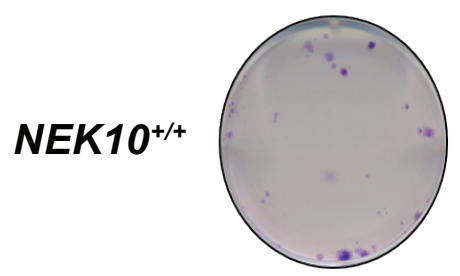

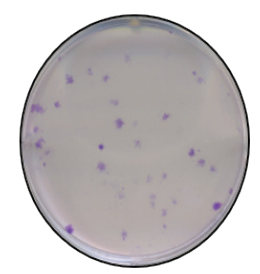
Be.

D
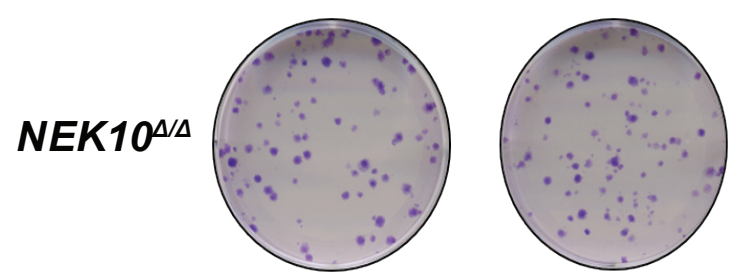

D

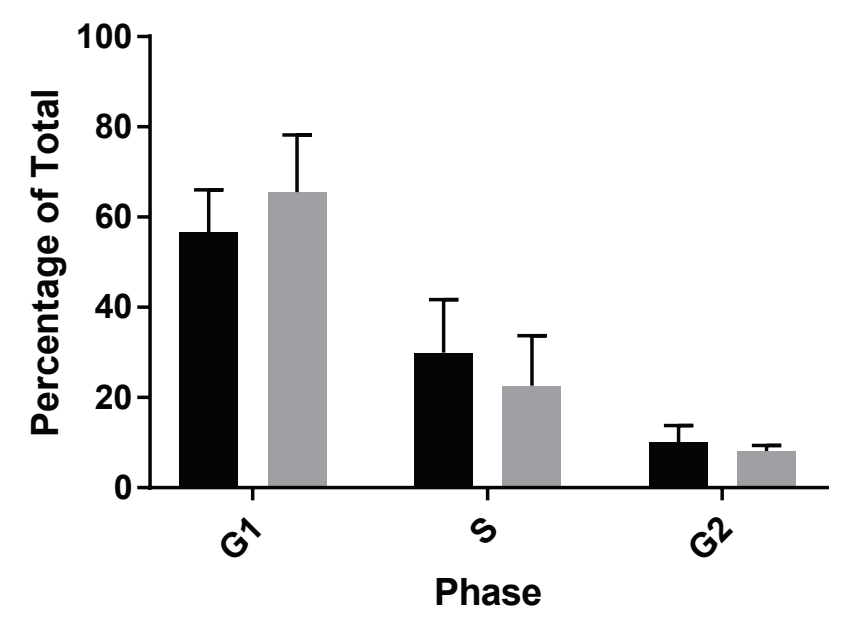

F

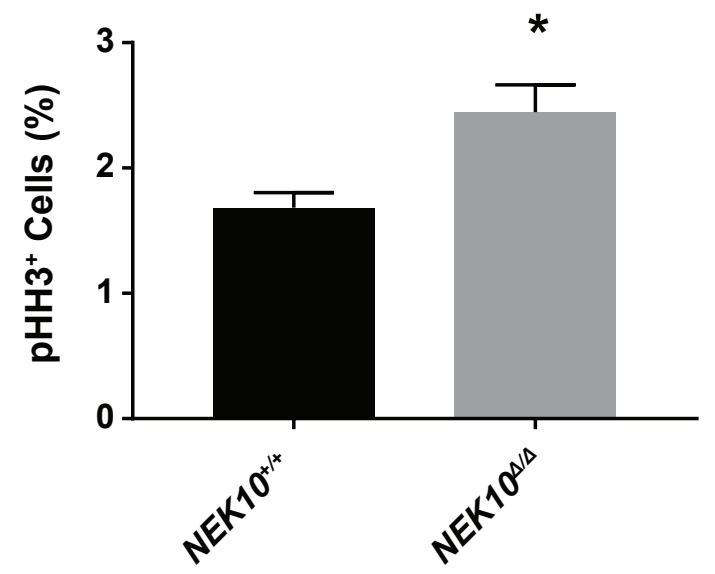


bioRxiv preprint doi: https://doi.org/10.1101/516971; this version posted January 10,2019 . The copyright holder for this preprint (which was not ertified by peer review) is the author/funder, who has granted bioRxiva license to display the preprint in perpetuity. It is made available under A
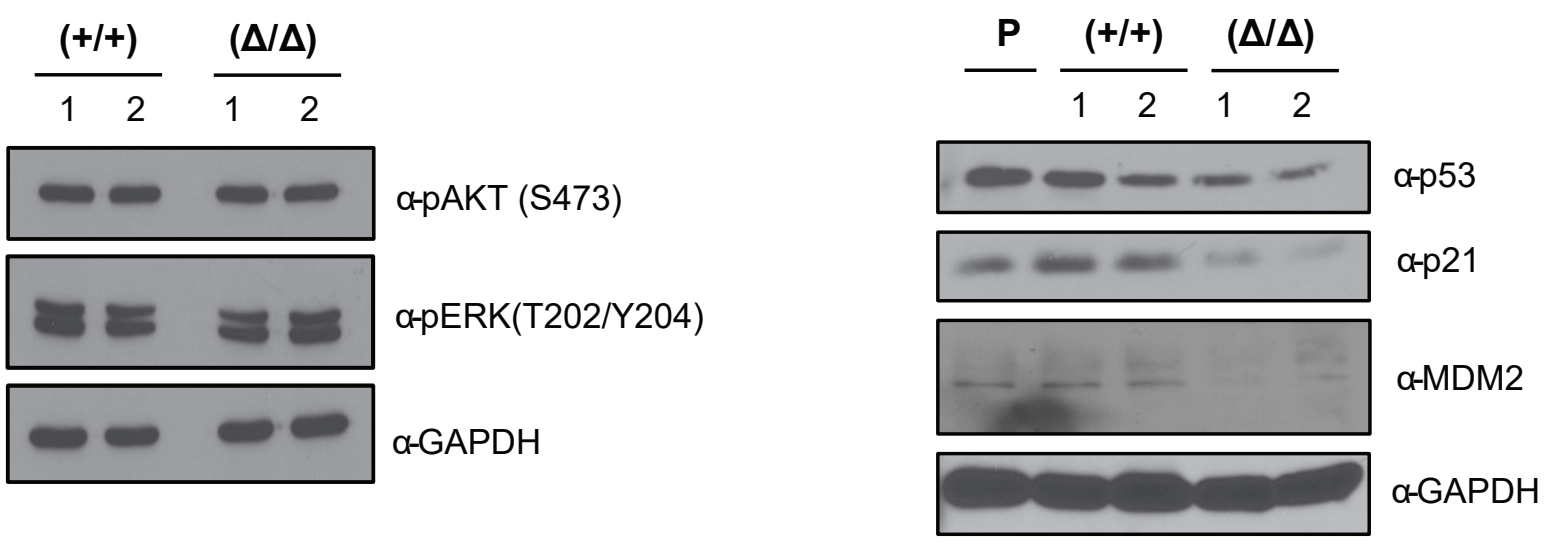

C

\section{NEK $10^{+/+}$}

$\begin{array}{lllllll}\text { CHX } & 0 & 30 & 60 & 90 & 120 & 240\end{array}$

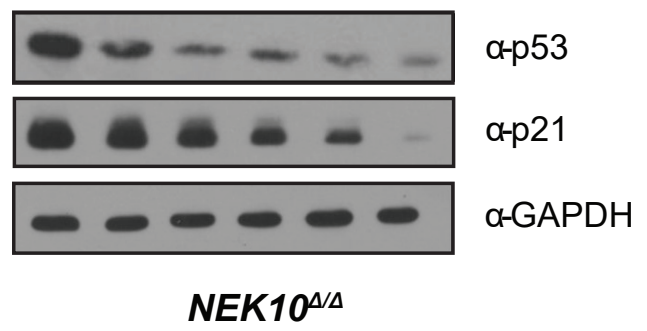

$\begin{array}{lllllll}\text { CHX } & 0 & 30 & 60 & 90 & 120 & 240\end{array}$

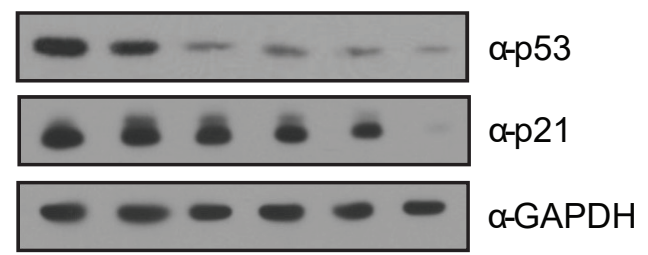

D

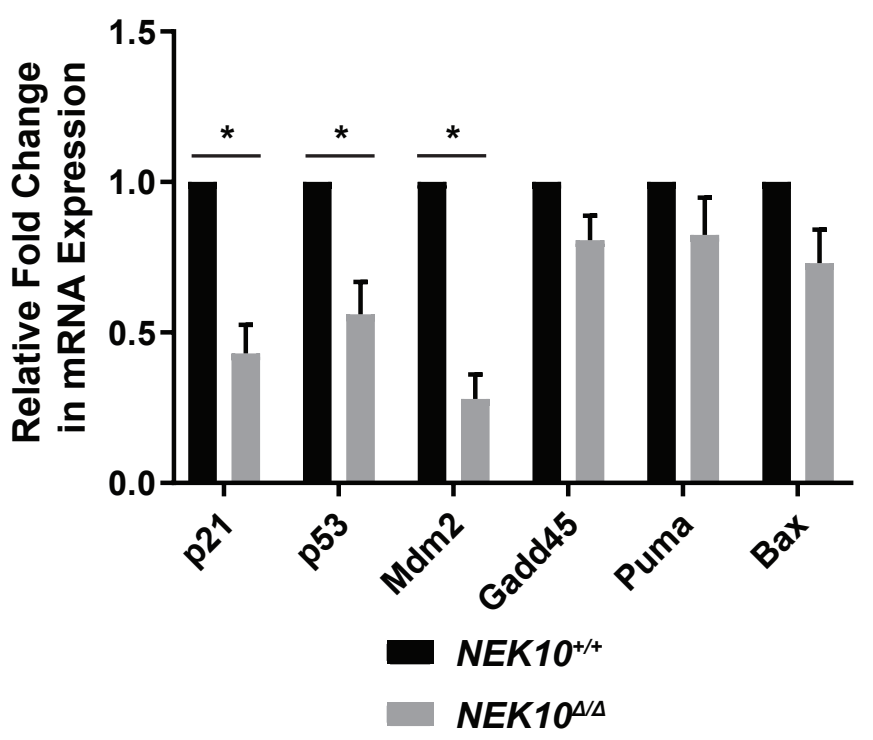

E

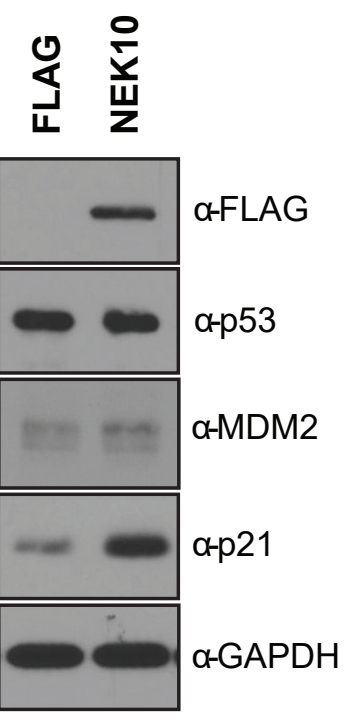

FIGURE 2. Haider et al. 
A

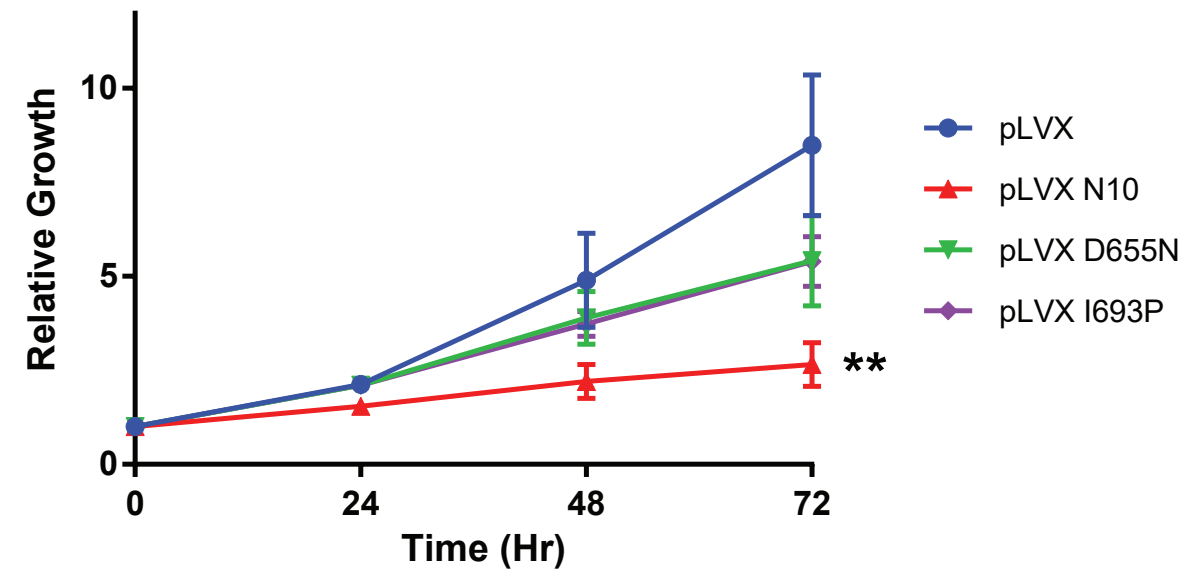

B

$\alpha-F L A G$

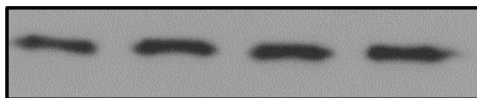

$\alpha-p 53$

$\alpha-p 21$

a-GAPDH

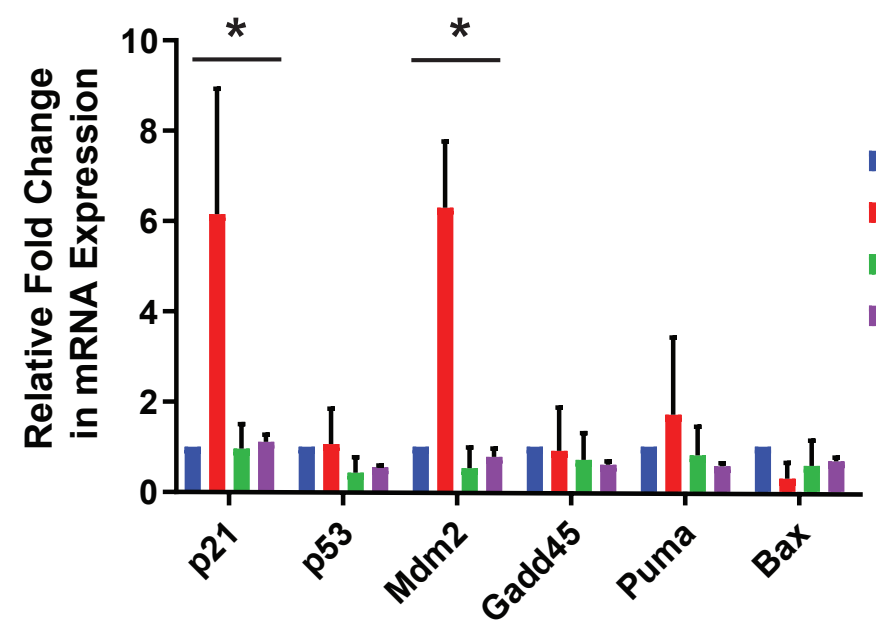


bioRxiv preprint doi: https://doi.org/10.1101/516971; this version posted January 10 , 2019. The copyright holder for this preprint (which was not A certified by peer review) is the author/funder, who has granted bioRxiv a licens display the preprint in perpetuity. It is made available under GST GST-P53 GST aCGSYK A5B Internationallicense.

FLAG N10

FLAG N10

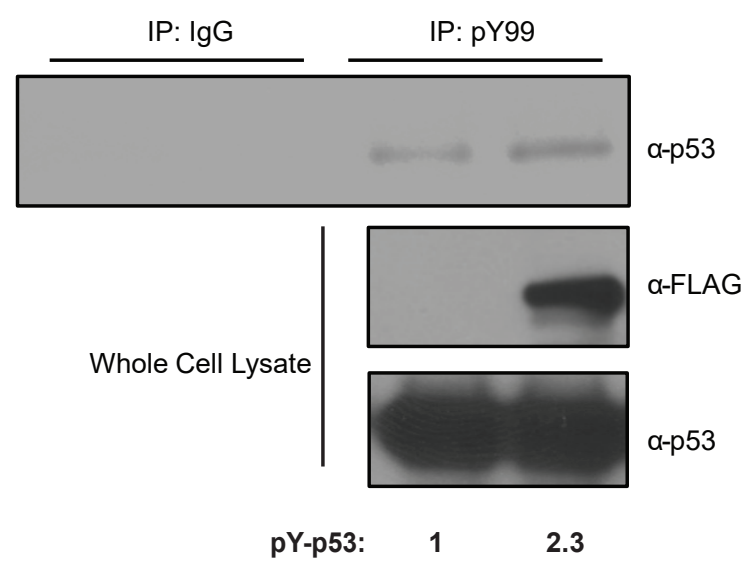

Autoradiograph

Input

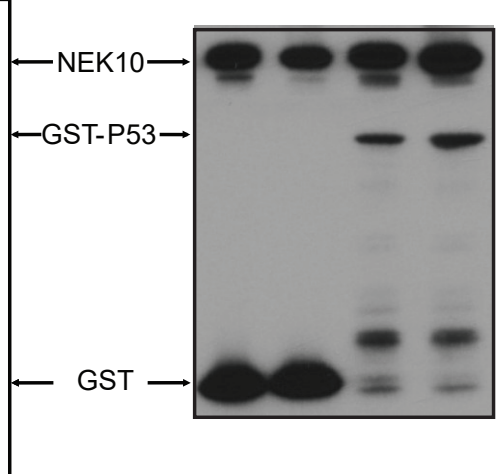

C

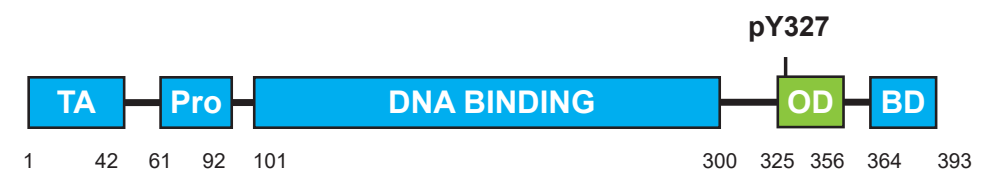

$\mathbf{E}$

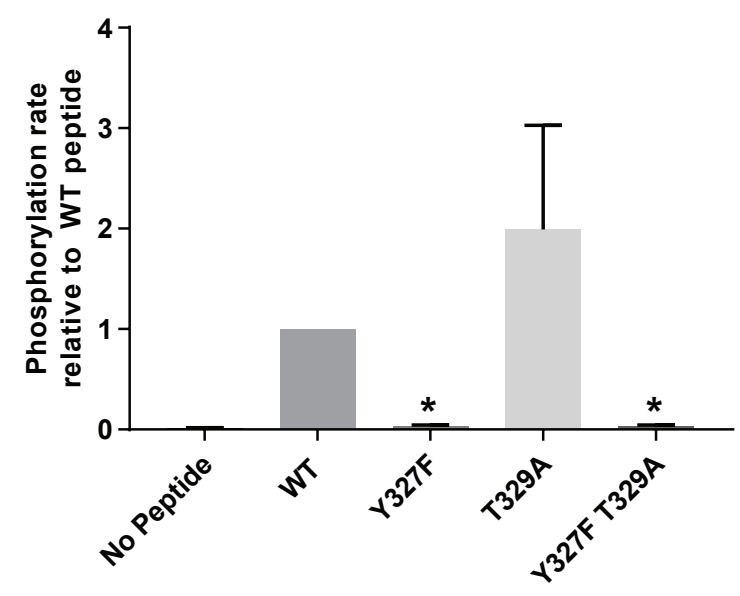

G

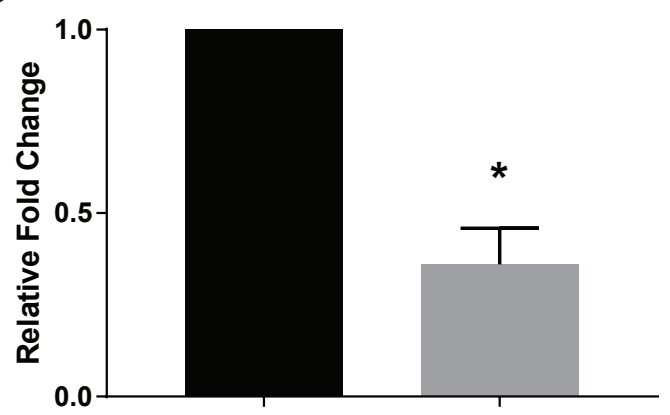

$\mathbf{F}$
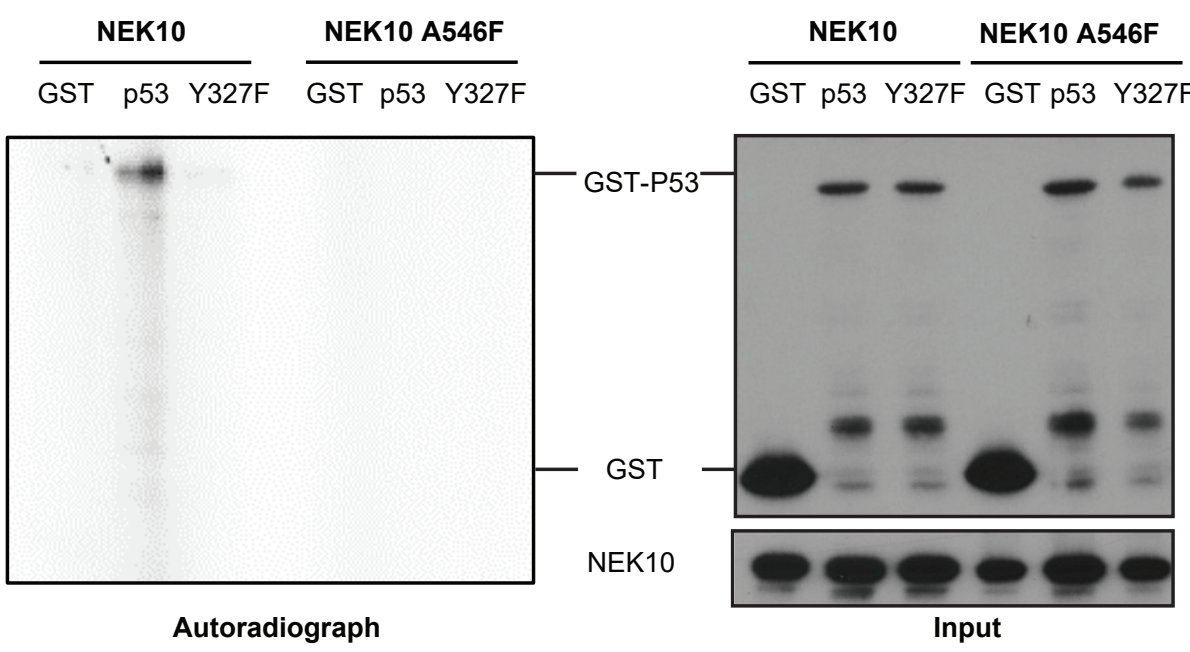

H

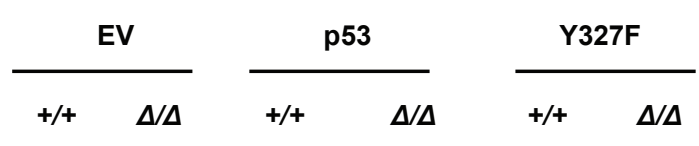

IP: pY99

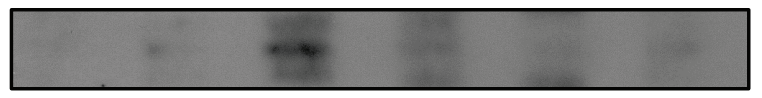

a-p53

Whole Cell Lysate

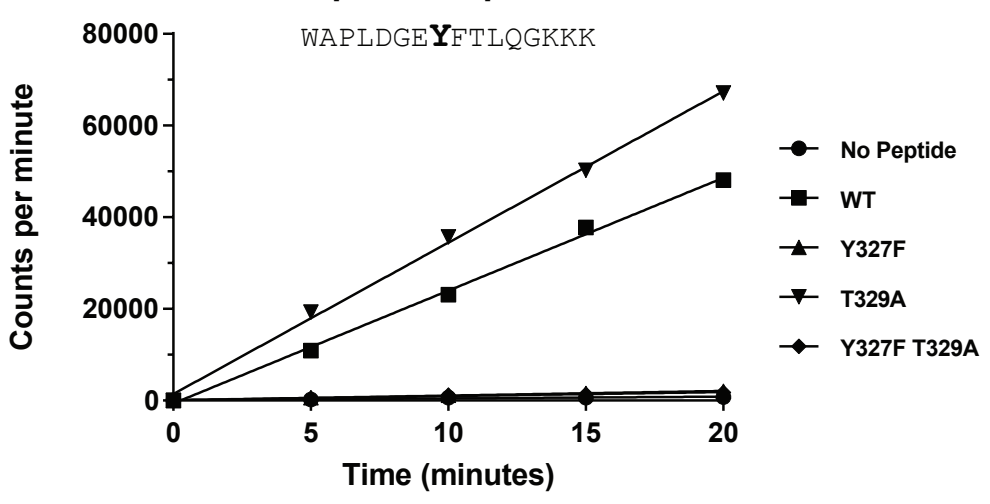

Peptide Sequence:

H. sapiens

PL DGEYF T LQ I

M.mulatta

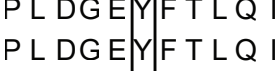

$P L D G E Y F T L Q$ I

M. musculus

P L DGEYF T L K I

Autoradiograph
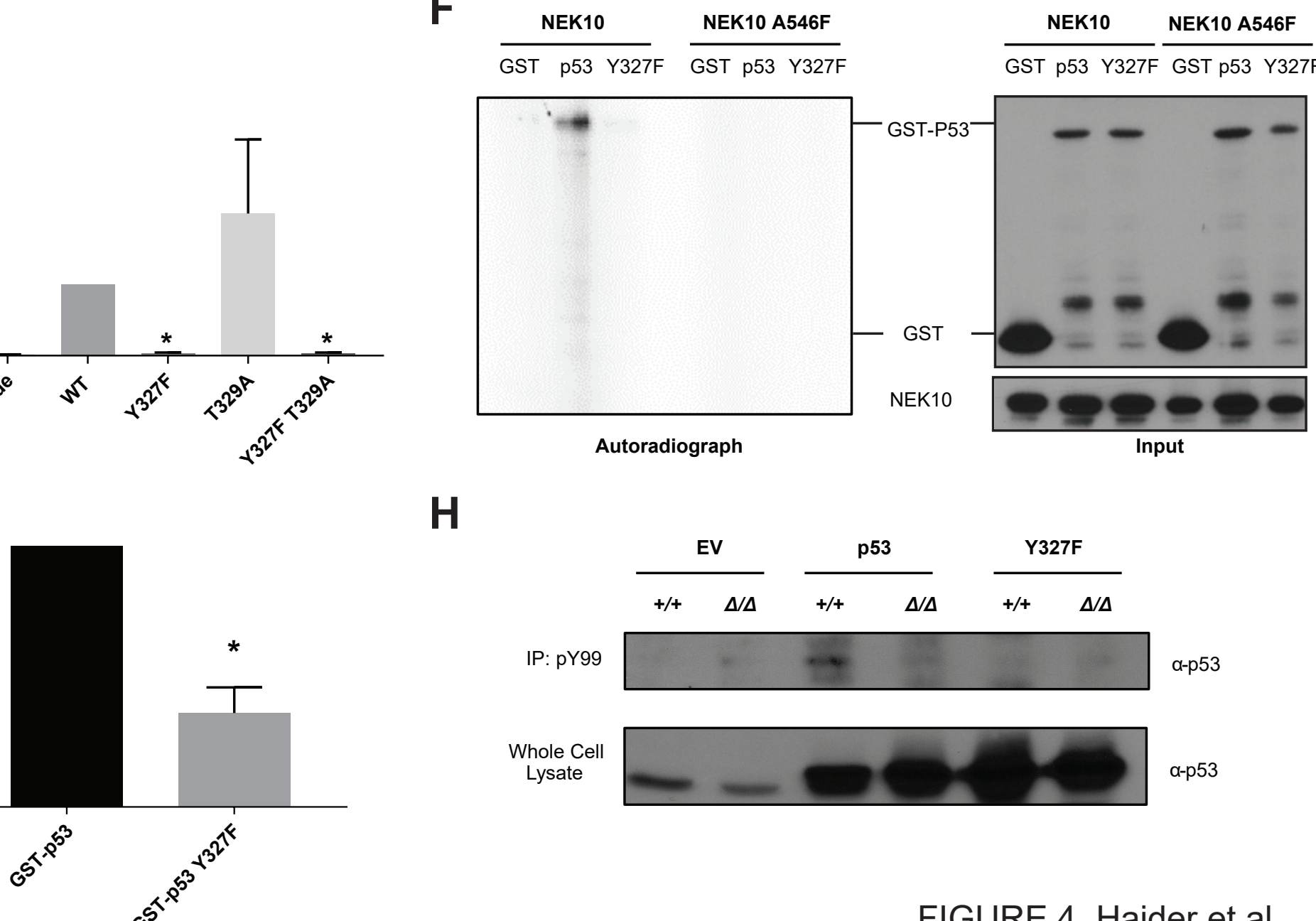
bioRxiv preprint doi: https://doi.org/10.1101/516971; this version posted January 10, 2019. The copyright holder for this preprint (which was not
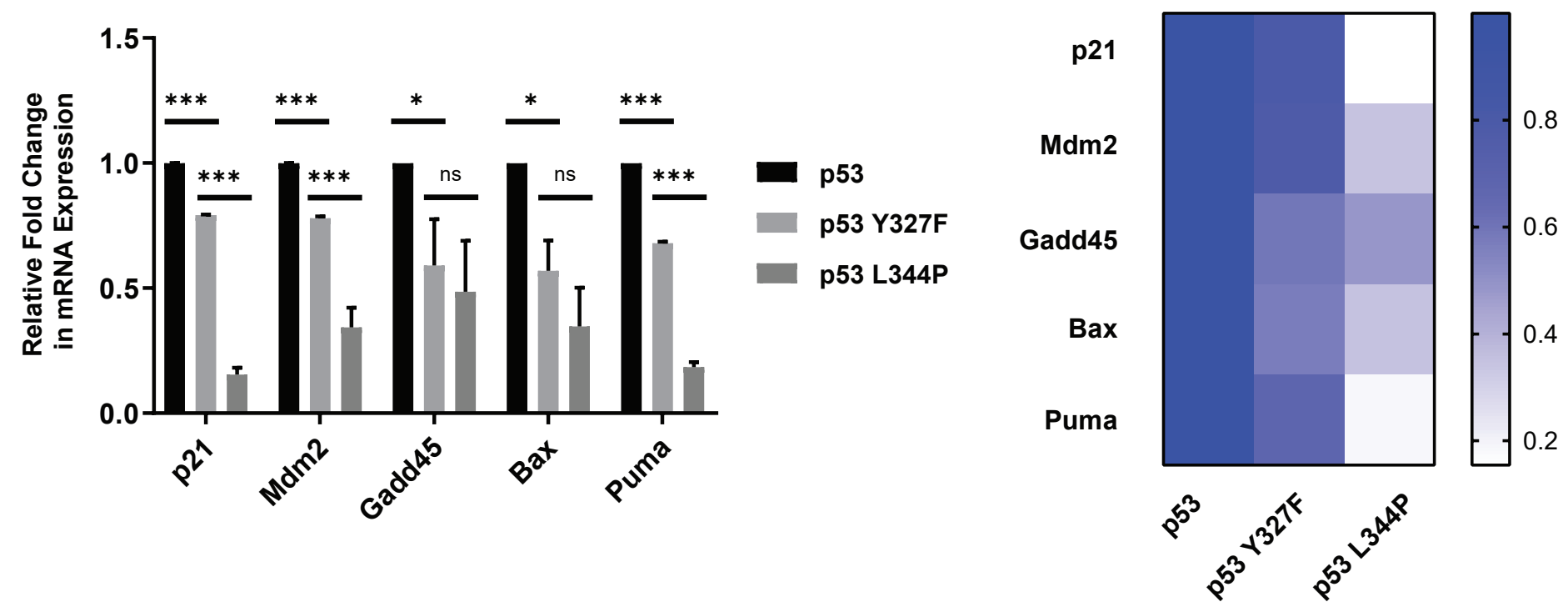

C

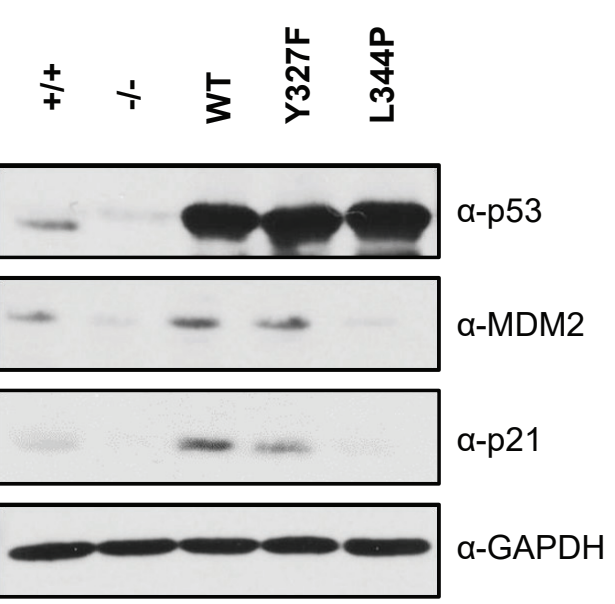

D

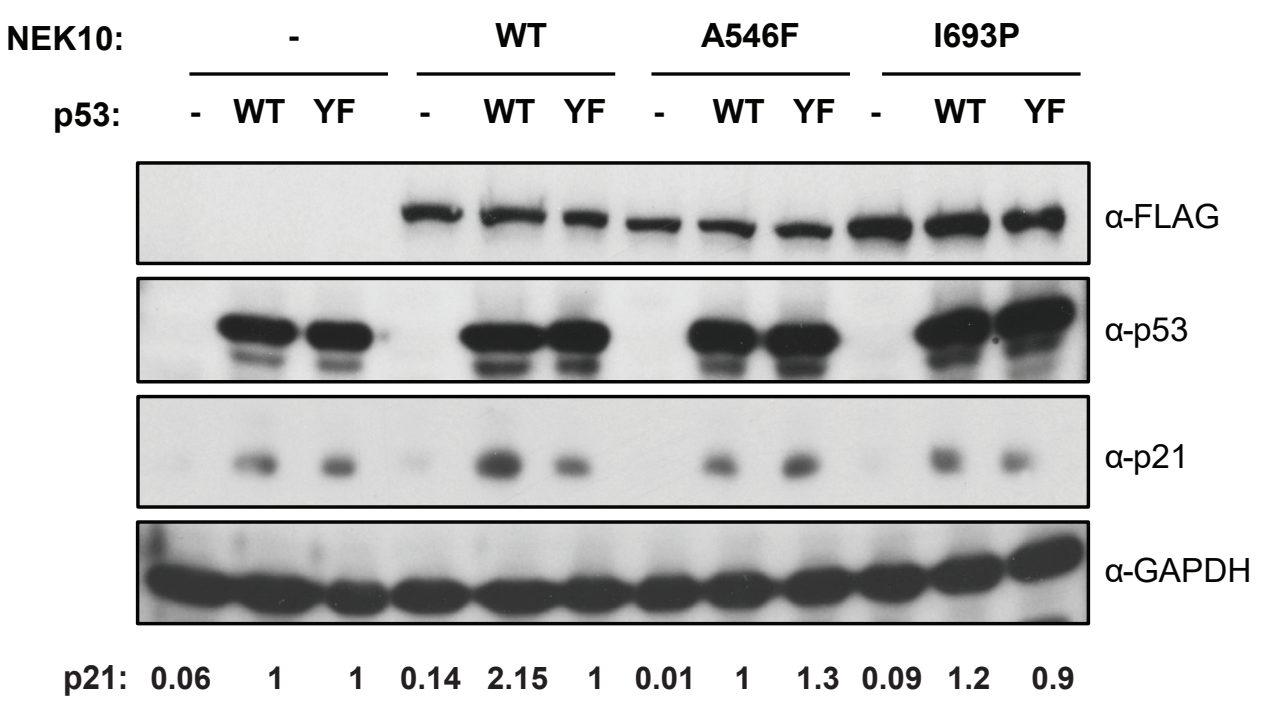


$\Delta$ bioRxiv preprint doi: https://doi.org/10.1101/516971; this versio Rosted January 10,2019 . The copyright holder for this preprint (which was not certified by peer review) is the author/funder, who has granted Rxiv a license to display the preprint in perpetuity. It is made available under
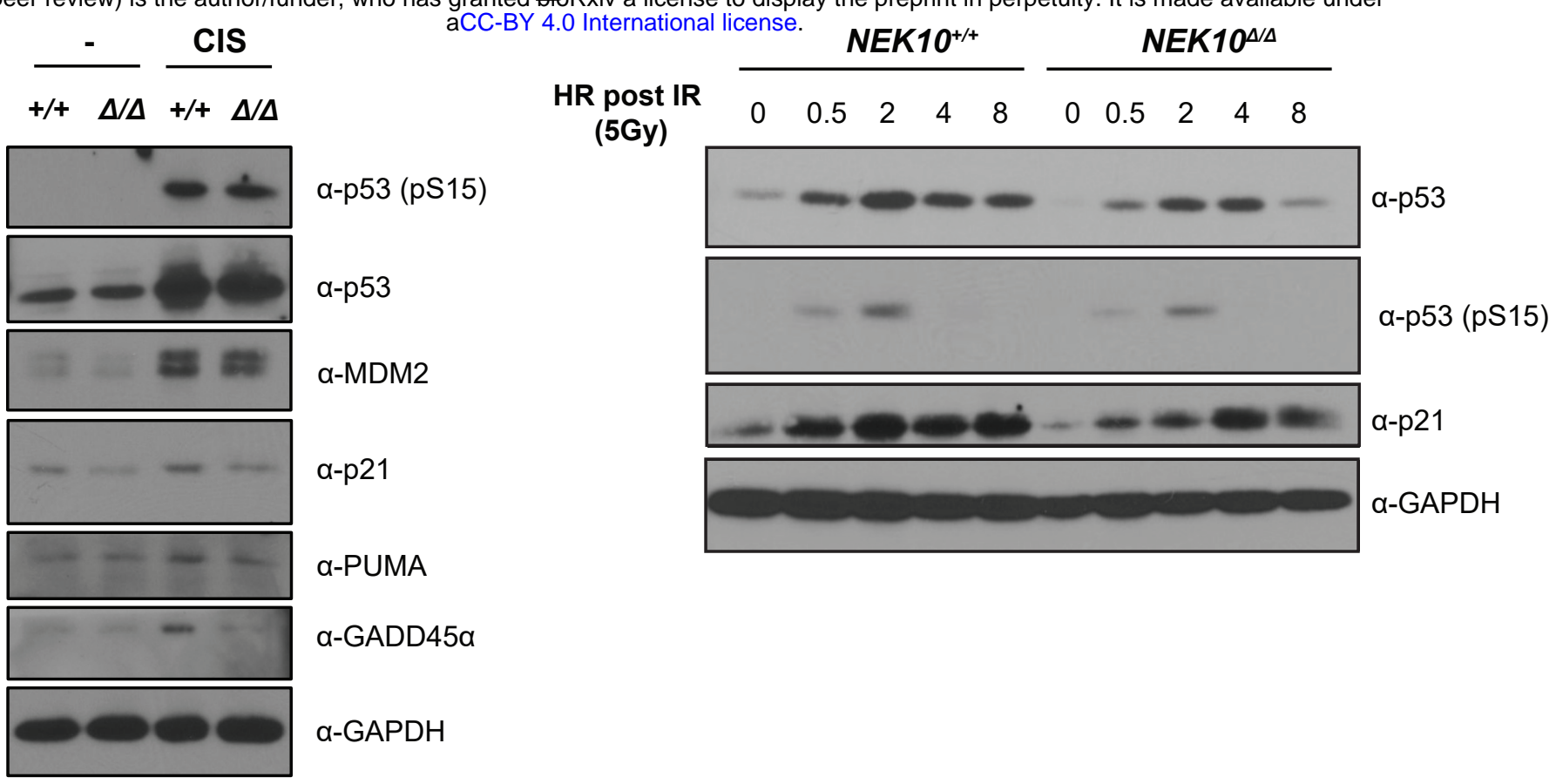

C
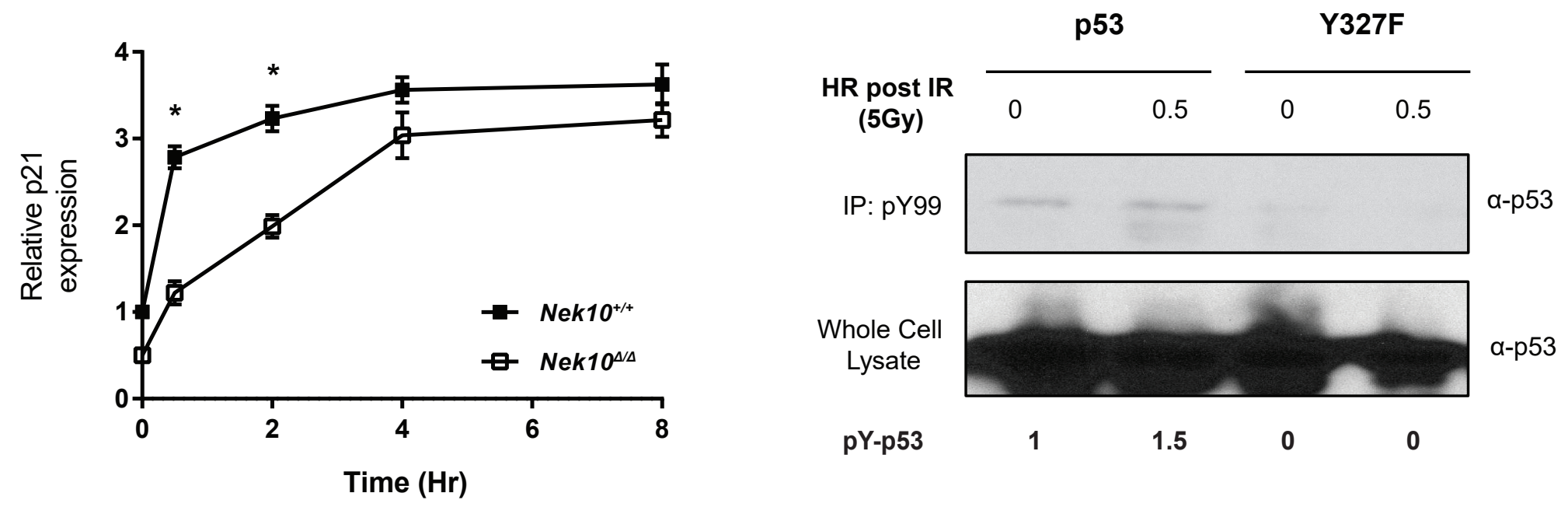

트

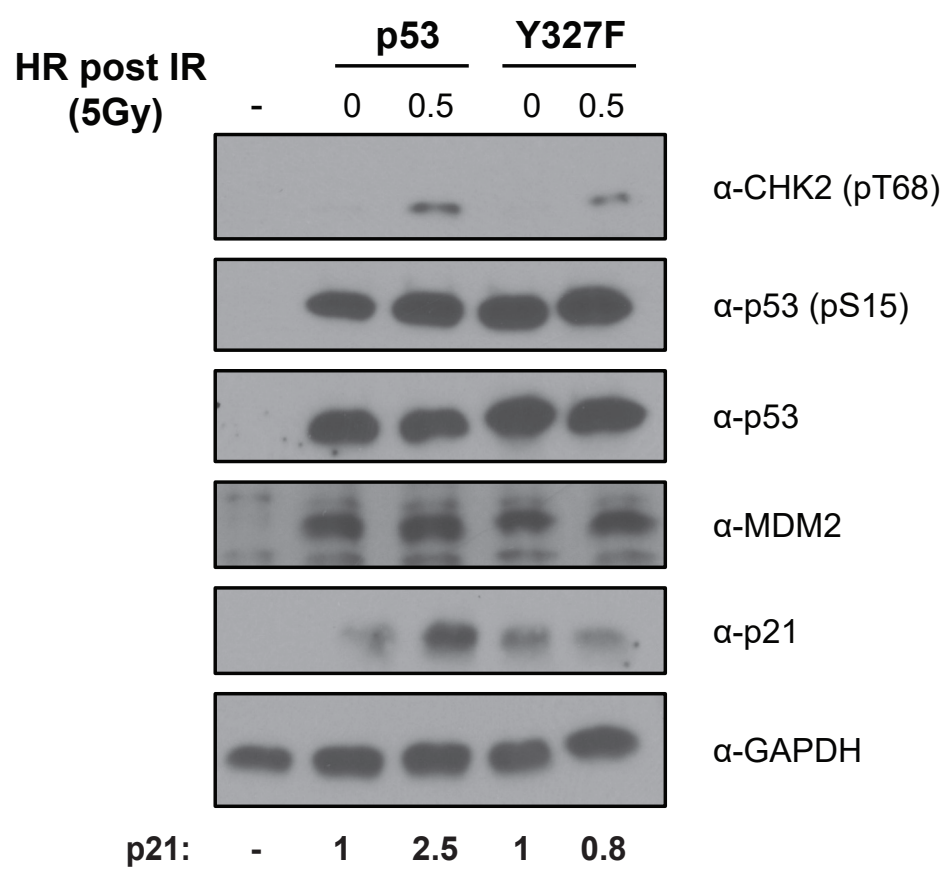

FIGURE 6. Haider et al. 
bioRxiv preprint doi: https://doi.org/10.1101/516971; this version posted January 10, 2019. The copyright holder for this preprint (which was not certified by peer review) is the author/funder, who has granted bioRxiv a license to display the preprint in perpetuity. It is made available under

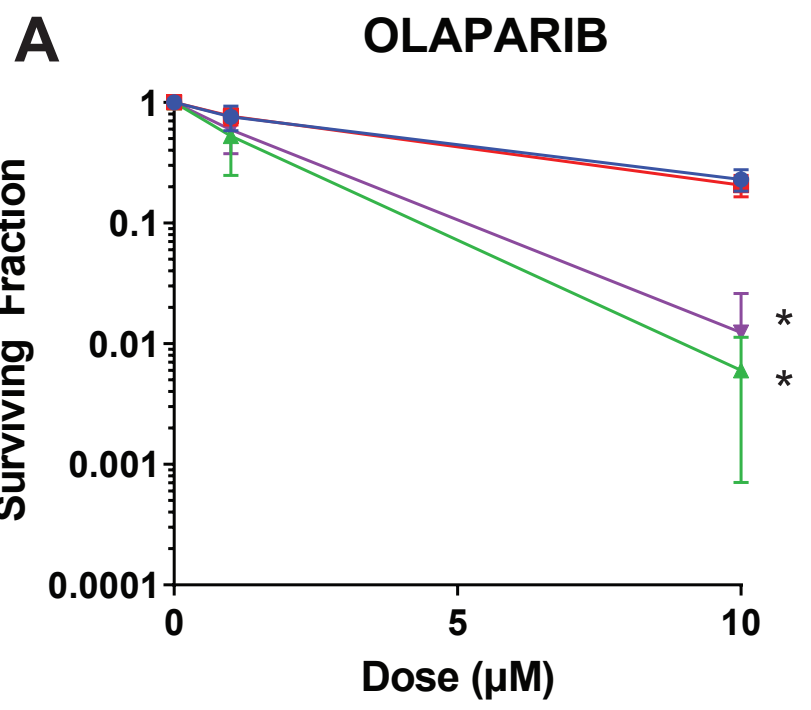

B

CISPLATIN

C

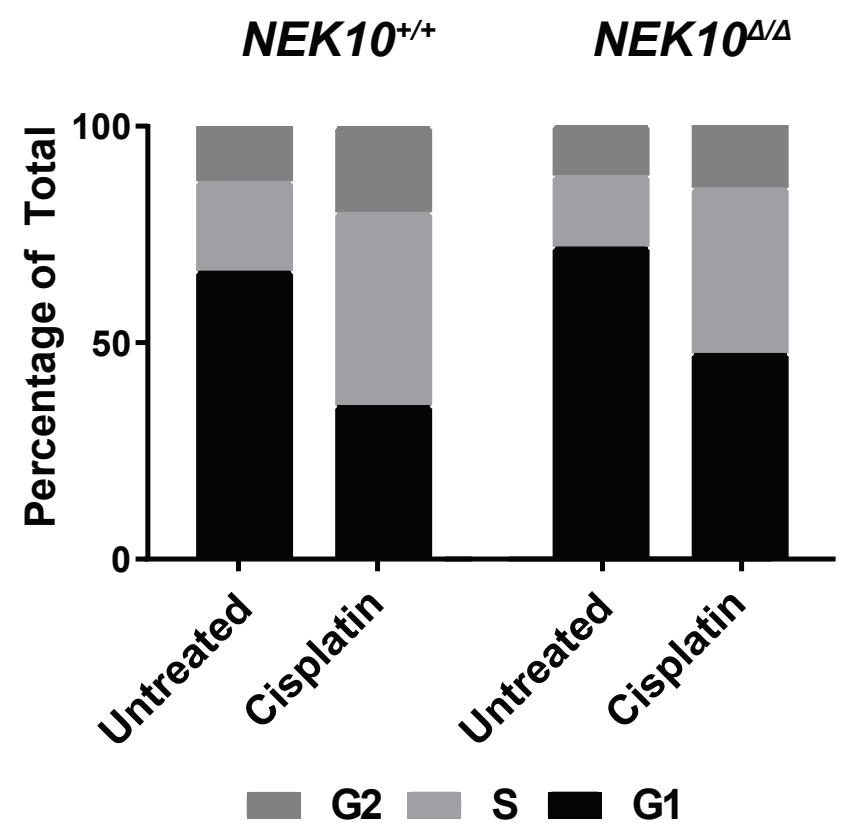

D

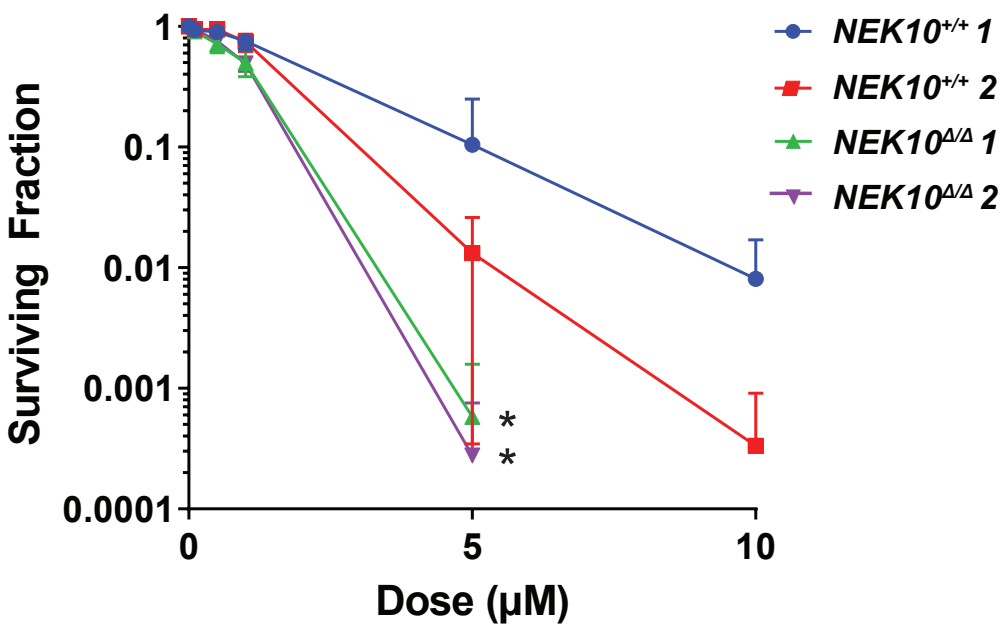

E

$\mathbf{F}$

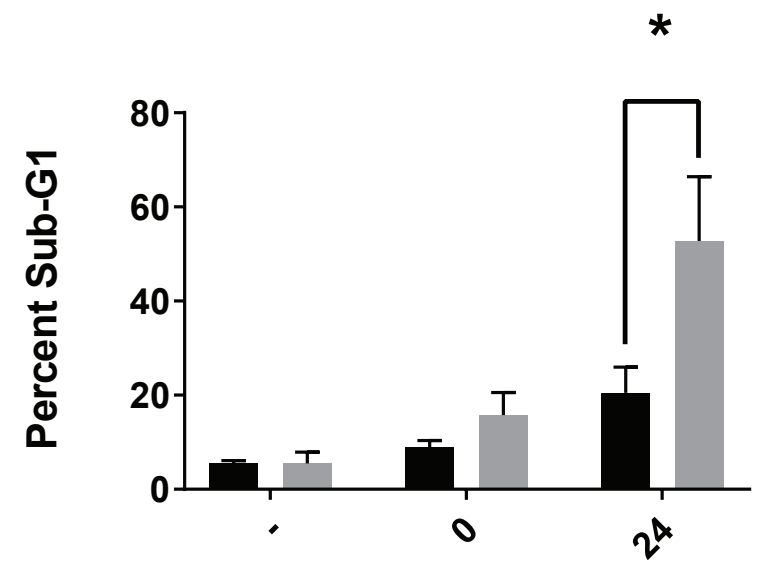

Time after Cisplatin Treatment (HR)

- NEK $10^{+/+}$

NEK10 $1 / \Delta$
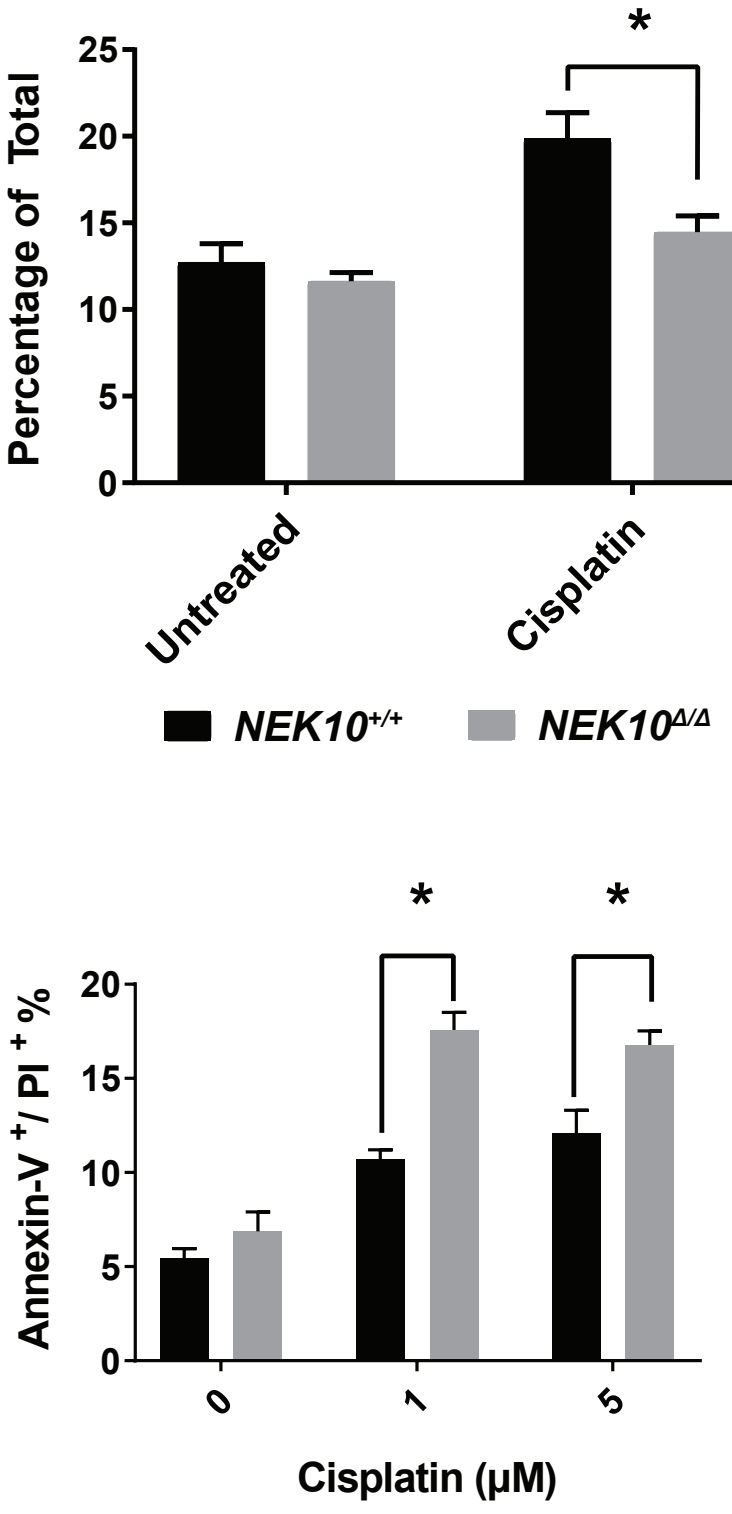

FIGURE 7. Haider et al. 
A

NEK10 Status

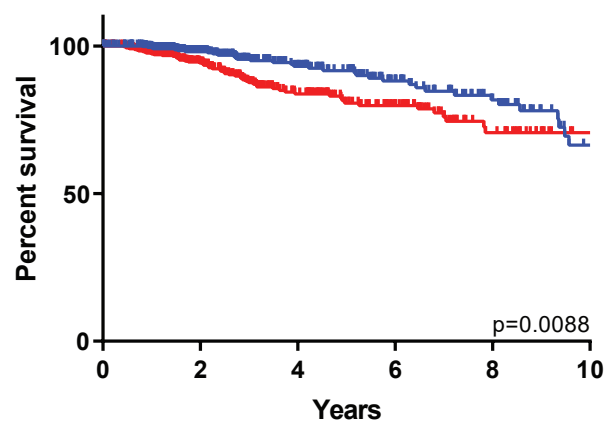

- High NEK10 - Low NEK10

$(\mathrm{n}=423) \quad(\mathrm{n}=426)$

C

Radiation Treatment

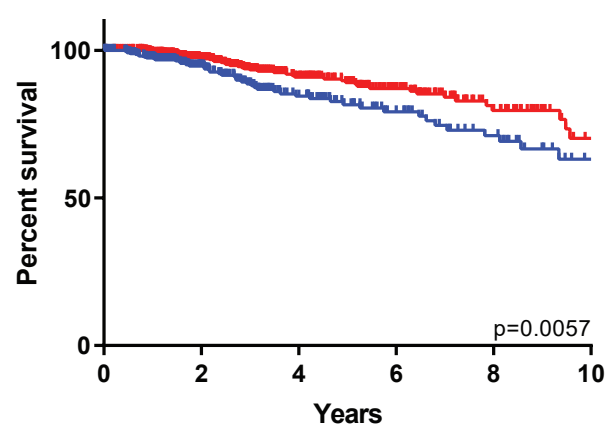

+ No Radiation Tx + Radiation Tx

$(n=369)$

$(n=480)$
WT TP53
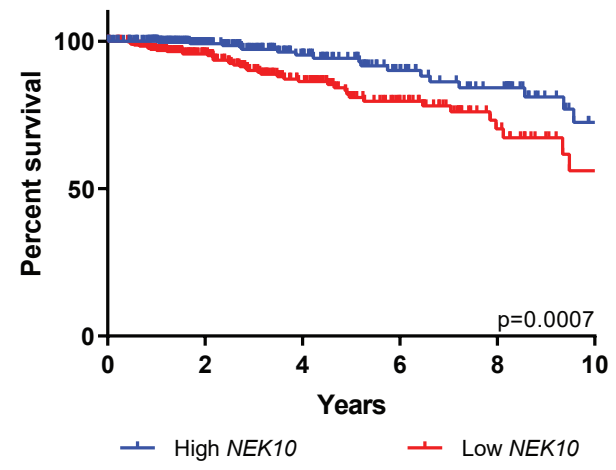

$(n=294)$

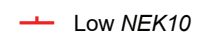

$(n=298)$

D

High NEK10

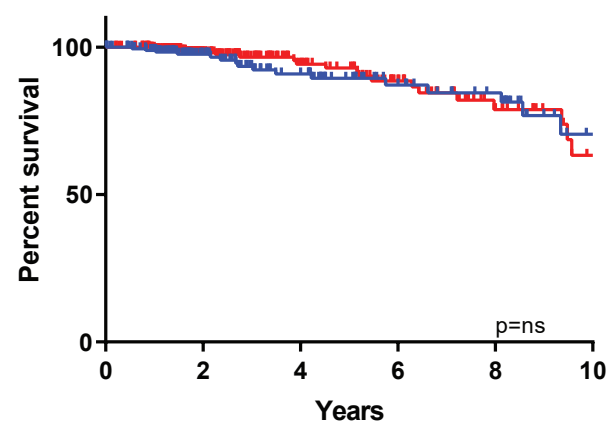

+ No Radiation Tx + Radiation Tx $(n=188)$

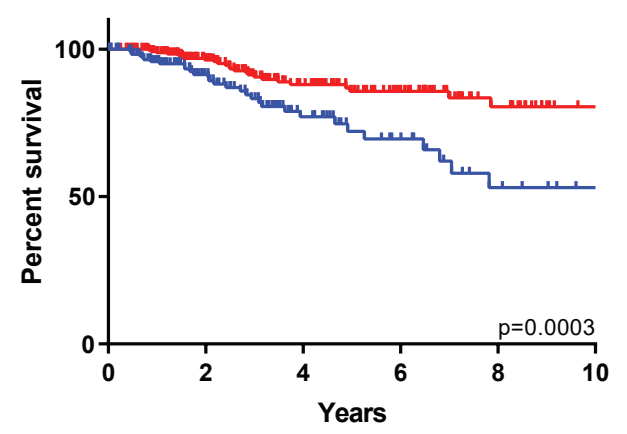

+ No Radiation Tx $(n=181)$

$(n=245)$

E

WT TP53 and Radiation

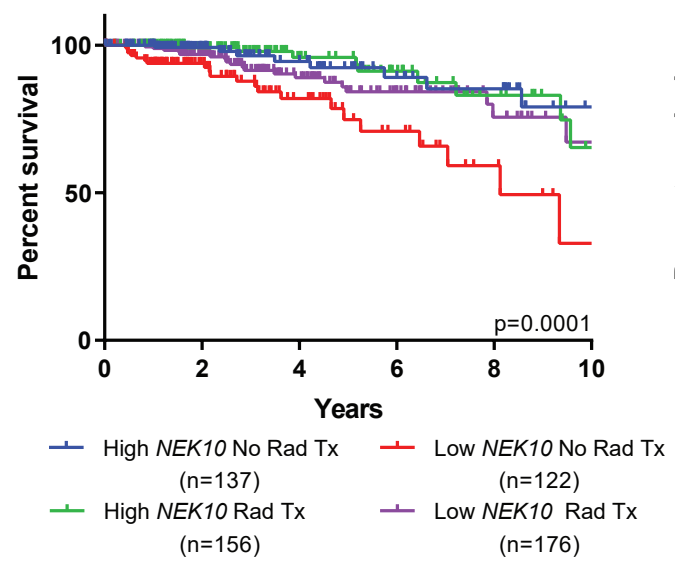

$(\mathrm{n}=176)$
MUT TP53 and Radiation

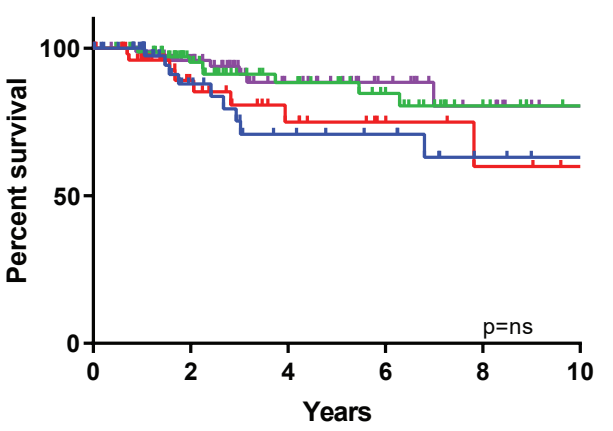

- High NEK10 No Rad Tx - Low NEK10 No Rad Tx $(n=55)$ $(n=55)$

- High NEK10 Rad Tx + Low NEK10 Rad Tx

$(n=77)$

\section{FIGURE 8. Haider et al.}


bioRxiv preprint doi: https://doi.org/10.1101/516971; this version posted January 10, 2019. The copyright holder for this preprint (which was not

i) aCC-BY 4.0 International license.

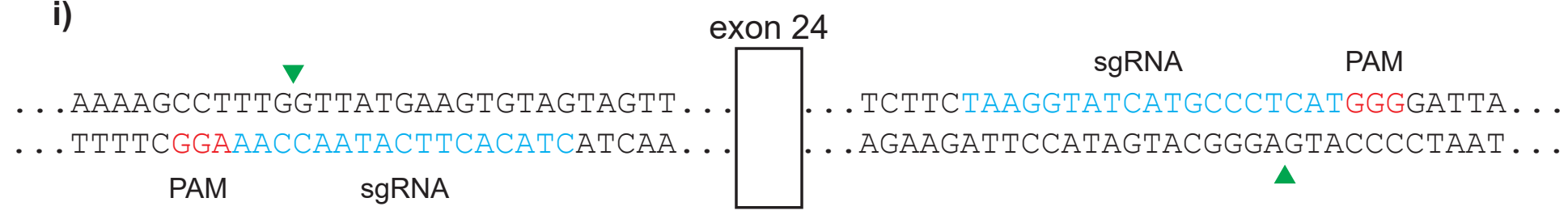

ii)

...GDKDKVTVTDFGL . . .

...GDKDKVTVTPRY * (STOP)

B

exon 24

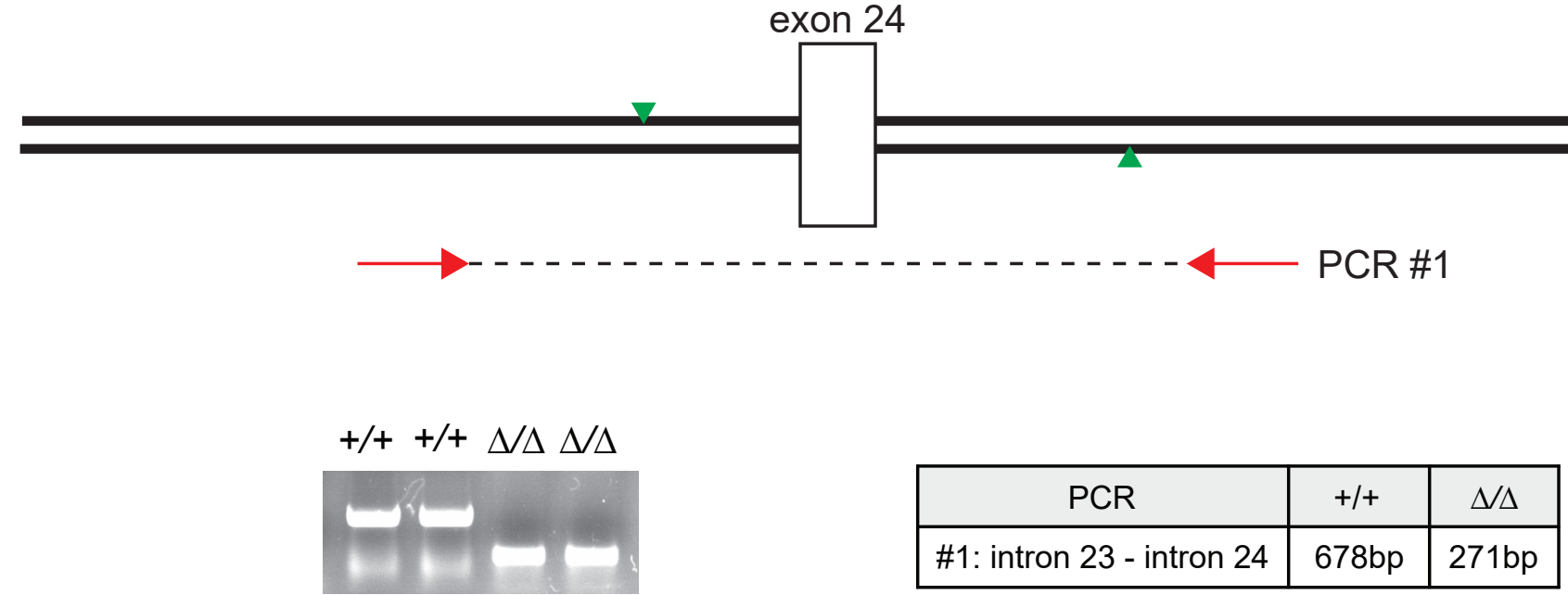

PCR \#1
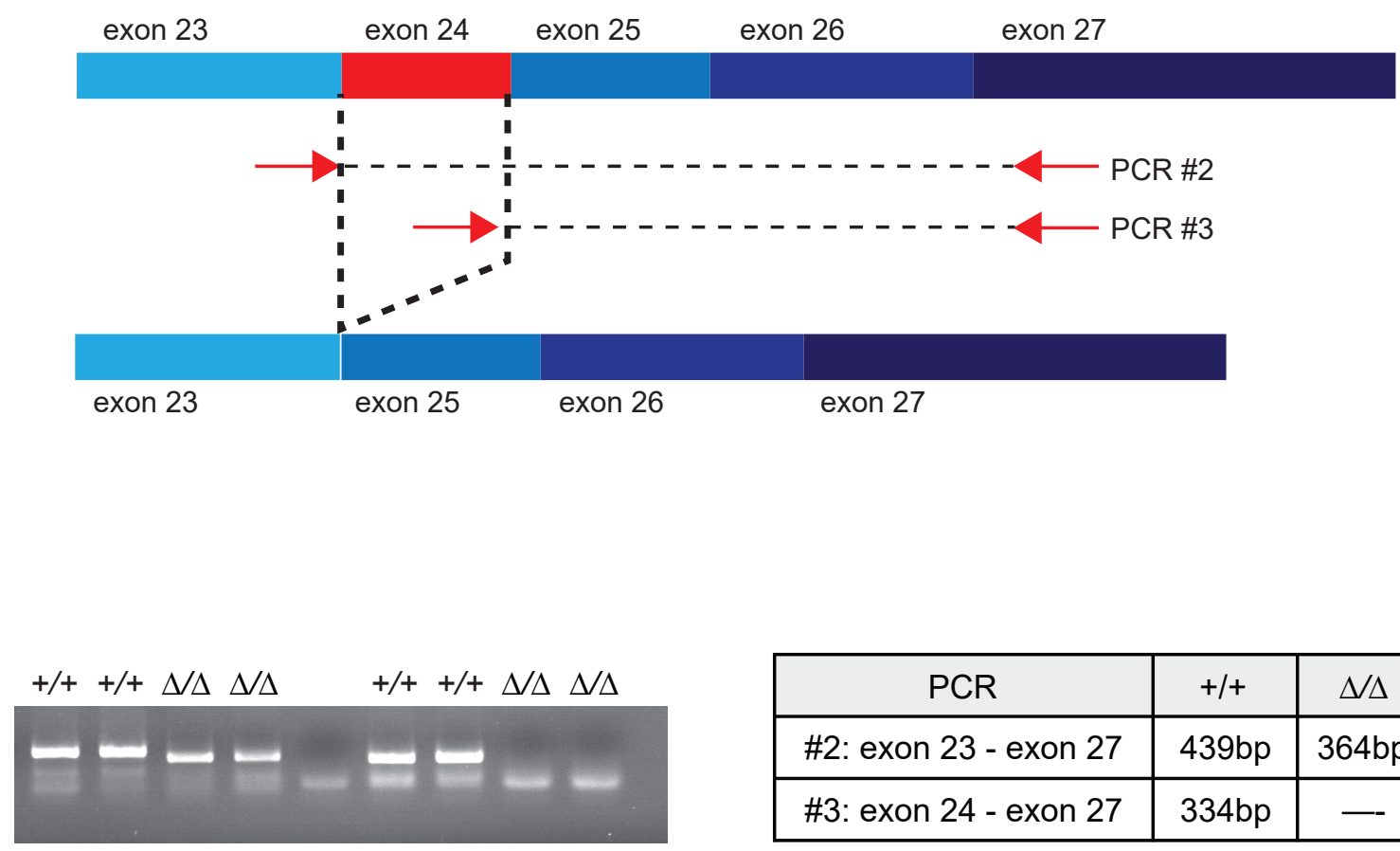

\begin{tabular}{|c|c|c|}
\hline PCR & $+/+$ & $\Delta / \Delta$ \\
\hline \#2: exon 23 - exon 27 & 439bp & 364bp \\
\hline \#3: exon 24 - exon 27 & 334bp & - \\
\hline
\end{tabular}

PCR \#2

PCR \#3

FIGURE S1. Haider et al. 
bioRxiv preprint doi: https://doi.org/10.1101/516971; this version posted January 10, 2019. The copyright holder for this preprint (which was not certified by peer review) is the author/funder, who has granted bioRxiv a license to display the preprint in perpetuity. It is made available under

A aCC-BY 4.0 International license.

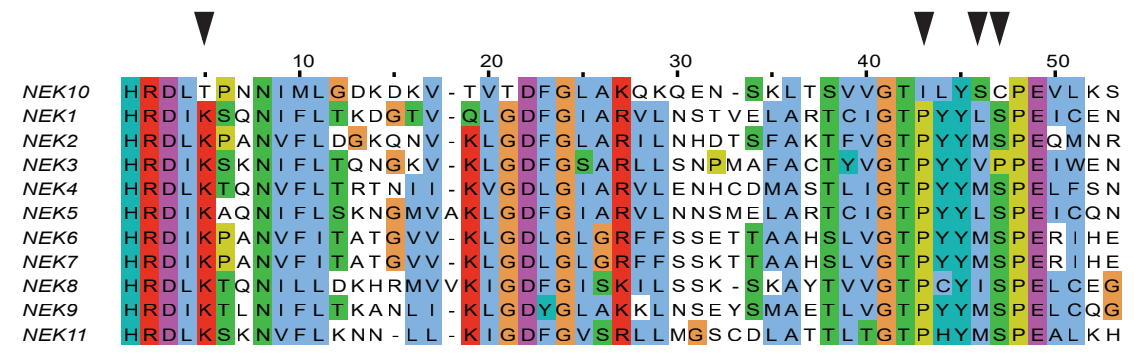

B

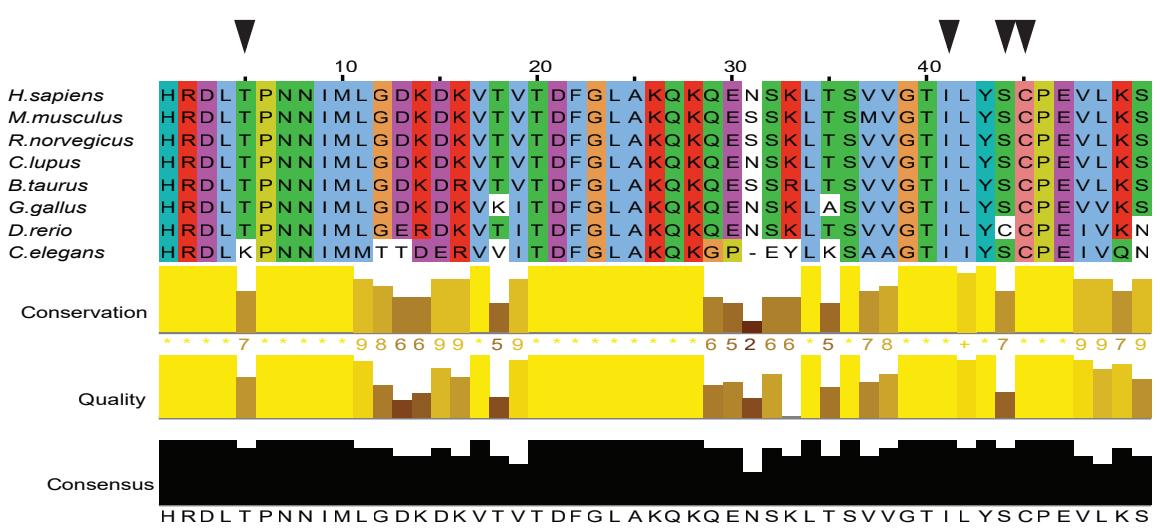

C

\begin{abstract}
N10 A546F T657K I693P S696M C697S
\end{abstract}

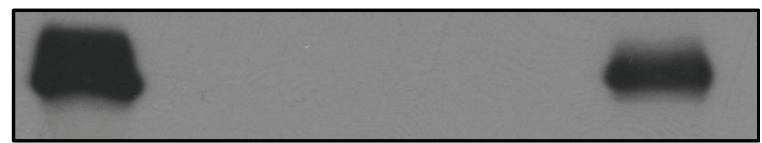

a-pY99

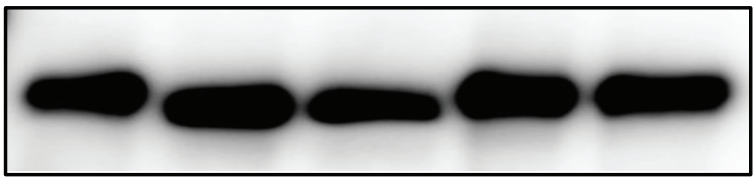

$\alpha-F L A G$

Auto Rad

\begin{tabular}{|l|c|c|c|}
\hline & $\begin{array}{c}\text { Tyrosine } \\
\text { Kinase }\end{array}$ & $\begin{array}{c}\text { Serine } \\
\text { Kinase }\end{array}$ & $\begin{array}{c}\text { Kinase } \\
\text { Activity }\end{array}$ \\
\hline $\mathrm{WT}$ & + & + & + \\
\hline $\mathrm{A} 546 \mathrm{~F}$ & - & - & - \\
\hline $\mathrm{D} 655 \mathrm{~N}$ & - & - & - \\
\hline $\mathrm{T} 657 \mathrm{~K}$ & - & + & + \\
\hline $\mathrm{I693P}$ & - & + & + \\
\hline $\mathrm{S} 696 \mathrm{M} / \mathrm{C} 697 \mathrm{~S}$ & + & + & + \\
\hline
\end{tabular}


bioRxiv preprint doi: https://doi.org/10.1101/516971; this version posted January 10,2019 . The copyright holder for this preprint (which was not certified by peer review) is the author/funder, who has granted bioRxiv a license to display the preprint in perpetuity. It is made available under aCC-BY 4.0 International license.

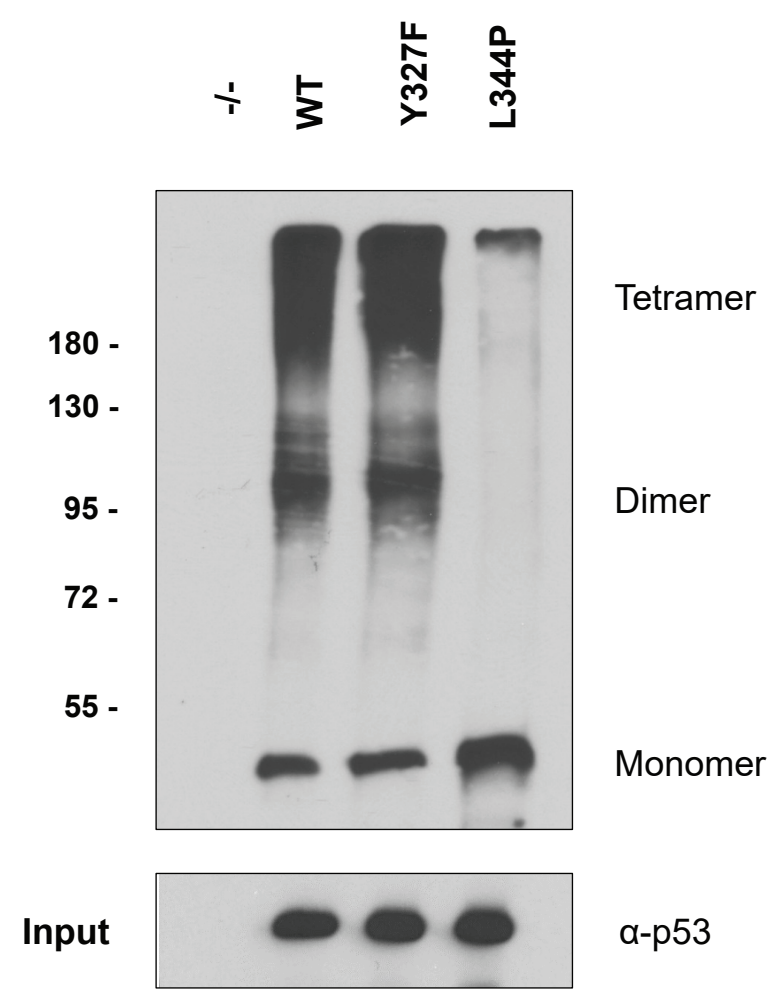

FIGURE S3. Haider et al. 